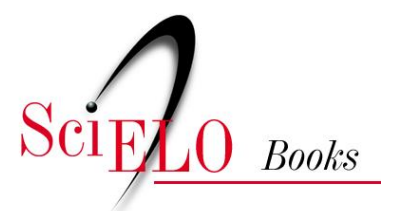

\title{
O sertão
}

\author{
Capistrano de Abreu
}

SciELO Books / SciELO Livros / SciELO Libros

ABREU, C. O sertão. In: Capítulos da história colonial [online]. Rio de Janeiro: Centro Edelstein de Pesquisa Social, 2009. pp. 89-157. ISBN: 978-85-7982-071-7.

https://doi.org/10.7476/9788579820717.0009.

\section{() pubulic}

This work is free of known copyright restrictions. http://creativecommons.org/publicdomain/mark/1.0/

Este trabalho está livre de restrições de direito de autor e/ou de direitos conexos conhecidas.

http://creativecommons.org/publicdomain/mark/1.0/

Esta obra está libre de restricciones conocidas de derechos autorales. http://creativecommons.org/publicdomain/mark/1.0/ 


\section{O SERTÃO}

A invasão flamenga constitui mero episódio da ocupação da costa. Deixa-a na sombra a todos os respeitos o povoamento do sertão, iniciado em épocas diversas, de pontos apartados, até formar-se uma corrente interior, mais volumosa e mais fertilizante que o tênue fio litorâneo.

$$
* * *
$$

Podemos começar pela capitania de São Vicente. O estabelecimento de Piratininga, desde a era de 1530, na borda do campo, significa uma vitória ganha sem combate sobre a mata, que reclamou alhures o esforço de várias gerações. Deste avanço procede o desenvolvimento peculiar de São Paulo.

O Tietê corria perto; bastava seguir-lhe o curso para alcançar a bacia do Prata. Transpunha-se uma garganta fácil e encontrava-se o Paraíba, encaixado entre a serra do Mar e a da Mantiqueira, apontando o caminho do Norte. Para o Sul estendiam-se vastos descampados, interrompidos por capões e até manchas de florestas, consideráveis às vezes, mais incapazes de sustarem o movimento expansivo por sua descontinuidade. A Este apenas uma vereda quase intransitável levava à beira-mar, vereda fácil de obstruir, obstruída mais de uma vez, tornando a população sertaneja independente das autoridades da marinha, pois um punhado de homens bastava para arrostar um exército, e abrir novas picadas, domando as asperezas da serra, rompendo as massas de vegetação, arrostando a hostilidade dos habitantes, pediria esforços quase sobre-humanos.

Sob aquela latitude, naquela altitude, fora possível uma lavoura semieuropeia, de alguns, senão todos os cereais e frutos da península. Ao contrário o meio agiu como evaporador: os paulistas lançaram-se a bandeirantes.

Bandeiras eram partidas de homens empregados em prender e escravizar o gentio indígena. $O$ nome provém talvez do costume tupiniquim, referido por Anchieta, de levantar-se uma bandeira em sinal de guerra. Dirigia a expedição um chefe supremo, com os mais amplos poderes, senhor da vida e morte de seus subordinados. Abaixo dele com 
certa graduação marchavam pessoas que concorriam para as despesas ou davam gente.

Figura obrigada era o capelão.

Meu capelão saiu para fora estando eu para sair para a campanha", escrevia Domingos Jorge Velho em novembro de 1692, "mandei-o buscar; não quis vir; de necessidade busquei o inimigo; sem ele morreram-me três homens brancos sem confissão, cousa que mais tenho sentido nesta vida; peço-lhe pelo amor de Deus me mande um clérigo em falta de um frade, pois se não pode andar na campanha e sendo com tanto risco de vida sem capelão". Montoya fala nestes "lobos vestidos de pieles de ovejas, unos hipocritones, los cuales tienen por oficio mientras los demás andan robando y despojando las iglesias y atando indios, matando y despedazando niños, ellos, mostrando largos rosarios que traen al cuello, lléganse á los padres [jesuítas espanhóis] pidenles confesion... y mientras están hablando de estas cosas van pasando las cuentas del Rosario muy aprisa.

Escravos serviam de carregadores. Compunha-se a carga de pólvora, bala, machados e outras ferramentas, cordas para amarrar os cativos, às vezes sementes, às vezes sal e mantimentos. Poucos mantimentos. Costumavam partir de madrugada, pousavam antes de entardecer, o resto do dia passavam caçando, pescando, procurando mel silvestre, extraindo palmito, colhendo frutos; as pobres roças dos índios forneciam-lhes os suplementos necessários, e destruí-las era um dos meios mais próprios para sujeitar os donos.

Se encontravam algum rio e prestava para a navegação, improvisavam canoas ligeiras, fáceis de varar nos saltos, aliviar nos baixios ou conduzir à sirga. Por terra aproveitavam as trilhas dos índios; em falta delas seguiam córregos e riachos, passando de uma para outra banda conforme lhes convinha, e ainda hoje lembram as denominações de PassaDois, Passa-Dez, Passa-Vinte, Passa-Trinta; balizavam-se pelas alturas, em busca de gargantas, evitavam naturalmente as matas, e de preferência caminhavam pelos espigões. Alguns ficaram tanto tempo no sertão que "volviendo a sus casas hallaron hijos nuevos, de los que teniendolos ya a ellos por muertos, se habian casado com sus mujeres, llevando tambien ellos los hijos que habian engedrado en los montes", informa-nos Montoya. Os jesuítas chamam à gente de S. Paulo mamalucos, isto é, filhos de cunhãs índias, denominação evidentemente exata, pois mulheres brancas não chegavam para aquelas brenhas.

Faltaram documentos para escrever a história das bandeiras, aliás sempre a mesma: homens munidos de armas de fogo atacam selvagens que se defendem com arco e frecha; à primeira investida morrem muitos dos assaltados e logo desmaia-lhes a coragem; os restantes, amarrados, são conduzidos ao povoado e distribuídos segundo as condições em que se organizou a bandeira. Nesta monotonia trágica os Caiapós introduziram mais tarde uma novidade: "a de nos cercar de fogo quando nos acham nos campos, a fim de que impedida a fuga nos abrasemos: este risco evitam já alguns lançando-lhe contrafogo, ou arrancando o capim para que não se lhe comuniquem as suas chamas; outros se untam com mel de pau, embrulhados em folhas ou cobertos de carvão, por troncos verdes ou paus queimados".

À parte geográfica das expedições corresponde mais ou menos o seguinte esquema: Os bandeirantes deixando o Tietê alcançaram o Paraíba do Sul pela garganta de São Miguel, desceram-no até Guapacaré, atual Lorena, e dali passaram a Mantiqueira, aproximadamente por onde hoje transpõe a E. F. Rio e Minas. Viajando em rumo de Jundiaí e Mogi, deixaram à esquerda o salto do Urupungá, chegaram pelo Paranaíba a Goiás. De Sorocaba partia a linha de penetração que levava ao trecho superior dos afluentes orientais do Paraná e do Uruguai. Pelos rios que desembocam entre os saltos do Urubupungá e Guaiará, transferiram-se da bacia do Paraná para a do Paraguai, chegaram a Cuiabá e a Mato-Grosso. Com o tempo a linha do Paraíba ligou o planalto do Paraná ao do S. Francisco e do Parnaíba, as de Goiás e Mato-Grosso ligaram o planalto amazônico ao rio-mar pelo Madeira, pelo Tapajós e pelo Tocantins. As bandeiras no século XVI devastaram sobretudo o Tietê, cujos numerosos Tupiniquins depressa desapareceram, e o alto Paraíba, chamado rio dos Surubis em Piratininga, segundo informa Glimmer; com o tempo foram-se alongando os raios do despovoamento e depredação, característico essencial e inseparável das bandeiras.

O movimento paulista para o sertão ocidental chocou-se com o movimento paraguaio à procura do mar: Ciudad Real, no Piqueri, próximo do salto das Sete Quedas, Vila Rica, no Ivaí, datam da segunda metade do século XVI, antes do Brasil cair sob o domínio da Espanha. Com estes 
colonos a gente de São Paulo cultivou a princípio boas relações; nas caçadas humanas foram às vezes sócios aliados. Além disso a viagem por terra do Paraguai para a costa fazia-se mais facilmente procurando Piratininga, do que repetindo a incômoda travessia de Cabeza de Vaca. A harmonia entrava assim no interesse de ambas as partes. Só mais tarde houve conflitos e as duas povoações desapareceram.

Por 1610, jesuítas castelhanos partidos de Asunción começaram a missionar na margem oriental do Paraná. Fundaram Loreto e San Ignacio, no Paranapanema, e em compasso acelerado mais onze reduções no Tibagi, no Ivaí, no Corumbataí, no Iguaçu. Transposto o Uruguai, assentaram outras dez entre o Ijuí e o Ibicuí, outras seis nas terras dos Tape, em diversos tributários da lagoa dos Patos. De San Cristóbal e Jesús María, no rio Pardo, poucas léguas os separavam agora do mar.

Esta catequese grandiosa não consistia simplesmente em verter as orações da cartilha para a língua geral, fazê-las repetir pela multidão ignara, submetendo-a à observância maquinal do culto externo.

Reduções, escreve um dos jesuítas contemporâneos que mais concorreram para avultarem, chamamos aos povoados dos índios, que vivendo à sua antiga usança, em matos, serras e vales, em escondidos arroios, em três, quatro ou seis casas apenas, separados, uma, duas, três e mais léguas uns de outros, os reduziu a diligência dos padres a povoações grandes e a vida política e humana, a beneficiar algodão com que se vistam, porque comumente viviam em nudez, ainda sem cobrir o que a natureza ocultava.

Não se imagina presa mais tentadora para caçadores de escravos. Por que aventurar-se a terras desvairadas, entre gente boçal e rara, falando línguas travadas e incompreensíveis, se perto demoravam aldeamentos numerosos, iniciados na arte da paz, afeitos ao jugo da autoridade, doutrinados no abanheen?

Houve alguns salteios contra as reduções desde o seu começo, mas a energia e o sangue frio dos jesuítas contiveram os arreganhos dos mamalucos, que se retiraram proferindo ameaças. Para pô-las em prática precisavam, porém, da convivência da gente de Asunción. Isto conseguiram em fins de 1628, e muito concorreu para assegurá-la Luís Cespedes Xeria, governador do Paraguai, casado em família fluminense, senhor de engenho no Rio. Fez por terra a viagem para seu governo; esteve em Loreto do
Pirapó e Santo Ignacio de Ipãumbuçu, admirou as igrejas, "hermosísimas iglesias, que no las he visto mejores en las Indias que he corrido del Perú y Chile", e fez sinal aos bandeirantes para avançarem.

A primeira das reduções invadidas, a de $\mathrm{S}$. Antônio, demorava na margem direita do Ivaí; invadiram depois San Miguel, Jesús María, San Pablo, San Francisco Xavier, no Tibagi; as outras, ainda mais depressa do que as agremiara uma inspiração ideal, foram sucessivamente destruídas pela fúria devastadora. Restavam apenas as de Loreto e San Ignacio, na Paranapanema; os jesuítas resolveram transplantá-las para abaixo do salto das Sete Quedas, entre o Paraná e o Uruguai, doloroso êxodo cuja narrativa ainda hoje penaliza. Depois de devastadas as missões de Guairá, os mamalucos passaram às do Uruguai e dos Tape. A entrada em Jesús María, no rio Pardo, já em águas da lagoa dos Patos, qual a descreve Montoya, dará ideia resumida dos processos empregados nestas expedições.

No dia de São Francisco Xavier (3 de dezembro de 1637), estando celebrando a festa com missa e sermão, cento e quarenta paulistas com cento e cinquenta tupis, todos muito bem armados de escopetas, vestido de escupis, que são ao modo de dalmáticas estofadas de algodão, com que vestido o soldado de pés à cabeça peleja seguro das setas, a som de caixa, bandeira tendida e ordem militar, entraram pelo povoado, e sem aguardar razões, acometendo a igreja, disparando seus mosquetes. Pelejaram seis horas, desde as oito da manhã até as duas da tarde.

Visto pelo inimigo o valor dos cercados e que os mortos seus eram muitos, determinou queimar a igreja, aonde se acolhera a gente. Por três vezes tocaram-lhe fogo que foi apagado, mas à quarta começou a palha a arder, e os refugiados viram-se obrigados a sair. Abriram um postigo e saindo por ele a modo de rebanho de ovelhas que sai do curral para o pasto, com espadas, machetes e alfanjes lhes derribavam cabeças, truncavam braços, desjarretavam pernas, atravessaram corpos. Provavam os aços de seus alfanjes em rachar os meninos em duas partes, abrir-lhes as cabeças e despedaçar-lhes os membros.

Compensará tais horrores a consideração de que por favor dos bandeirantes pertencem agora ao Brasil as terras devastadas? 
Apenas vagamente se conhece o caminho seguido nas bandeiras contra Guairá, Uruguai e Tape. Certamente Sorocaba, último povoado, representava papel importante. Em canoas ou balsas feitas no planalto desciam os rios, e uma ou outra que garrava servia de aviso do perigo iminente às reduções; eram, pois, viagens mistas. À volta, as jornadas deviam ser inteiramente por terra; de outro modo não poderiam trazer as chusmas de prisioneiros de coleira, amarrados uns aos outros.

Que destino davam a esta gente? Diz-nos Montoya que eram empregados em transportar nas costas para a marinha carne de vaca e porco; naturalmente carregariam sal na volta; outros passavam para o Rio, onde havia interessados nestas piratarias; outros finalmente juntavam-se nas fazendas dos administradores. Em campanha "las mujeres que en este, y otros pueblos (que destruyeron) de buen parecer, casadas, solteras o gentiles, el dueño las encerraba consigo en un aposento, com quien pasaba las noches al modo que un cabron en un curral de cabras".

O número considerável dos escravizados nas reduções jesuíticas manifesta-se na frequência de Carijós, chamavam em São Paulo aos Guaranis. Estes índios, devidamente amestrados, serviam também para as conquistas de outros; eram o grosso das forças dos bandeirantes, cujo papel se limitava ao de oficiais.

Os sucessos dos Tape provaram mais uma vez não haver remédio em Asunción, Rio ou Bahia. Os missionários esperavam ser mais felizes no além-mar e embarcaram Antonio Ruiz de Montoya para Madrid, Francisco Dias Taño para Roma. Conseguiu este bulas e censuras fulminantes, trouxe aquele as ordens mais precisas e encarecidas para as autoridades coloniais. Tudo perdido. Conhecidas as letras pontifícias no Rio, alborotou-se a população, e a bula ficou suspensa. A irritação propagou-se pela marinha e intensificou-se em serra acima. Defendidos por seu caminho inexpugnável, os paulistas expulsaram os jesuítas que só voltaram anos depois, à força de negociações e concessões. Implantou-se, portanto, o sistema seguido nas terras espanholas de encomendas ou administração dos índios; algumas encomendas por testamento couberam finalmente à Companhia de Jesus. Imagina-se mal neste figurino oportunista a consciência heróica de Manuel da Nóbrega.

Montoya conseguiu licença para aparelhar os índios com armas de fogo e adestrá-los na arte militar. Em breve os bandeirantes perderam a superioridade: derrotados, procuraram conquistas mais fáceis, na serra de Maracaju, no alto Paraguai, entre os Chiquitos, e por fim entre o gentio de corso, de língua travada. Esta caçada não rendia tanto, as bandeiras foram perdendo parte dos primeiros atrativos e decairam. Das reduções destruídas nunca mais se restabeleceram novamente fundados sete povos, mais tarde incorporados ao Brasil, como veremos.

Melhores serviços prestaram os paulistas na Bahia e ao Norte do rio S. Francisco. Em torno do Paraguaçu reuniram-se tribos ousadas e valentes, aparentadas aos Aimorés convertidos no princípio do século, que invadiram o distrito de Capanema, trucidaram os moradores e vaqueiros do Aporá, e avançaram até Itapororocas. Pouco fizeram expedições baianas mandadas contra eles, e houve a ideia de chamar gente de São Paulo. Acudindo ao convite Domingos Barbosa Calheiros embarcou em Santos; na Bahia se dirigiu para Jacobinas, mas deixou-se iludir por Paiaiás domesticados, e nada fez de útil. Acompanhando-o na jornada mais de duzentos homens brancos, raros tornaram do sertão.

Com este malogro não admira se repetissem as incursões de Tapuias, a ponto de a 4 de março de 1669 ser-lhes declarada guerra e outra vez convidados paulistas para fazê-la. em agosto de 1671 chegou a gente embarcada, com cuja condução a câmara do Salvador despendeu mais de dez contos de réis. Eram dois os chefes principais, Brás Rodrigues de Arzão e Estêvão Ribeiro Baião Parente. Fizeram de Cachoeira base das operações que duraram anos. Brás Rodrigues retirou-se depois de tomar, na margem esquerda do Paraguaçu, a aldeia do Camisão. Estêvão Ribeiro guerreou sobretudo na margem direita, onde conquistou a aldeia de Massacará. Em paga dos serviços foi-lhe dado o senhorio de uma vila chamada de João Amaro, nome de seu filho. A vila, depois de vendida com as suas terras a um ricaço da Bahia, extinguiu-se; o epônimo ainda é lembrado nos catingais baianos.

A estas expedições marítimas sucederam outras por via terrestre. Talvez a mais antiga fosse a de Domingos de Freitas de Azevedo, de quem apenas consta haver sido derrotado no rio S. Francisco. Facilitaram estas entradas a abundância de matas no trecho superior do rio, as suas condições de navegabilidade dentro do planalto, o emprego de canoas. Paulistas houve que fizeram canoas e desceram para vendê-las próximo do trecho encachoeirado, onde a escassez da vegetação tornava preciosa a mercadoria. 
Das expedições feitas pelo interior conhecemos a de Domingos Jorge Velho, Matias Cardoso de Almeida, Morais Navarro, todos empregados em combater os Paiacus, Janduís, Icós, nas ribeiras do Açu e do Jaguaribe. Domingos Jorge auxiliou a debelação dos Palmares, mocambo de negros localizado nos sertões de Pernambuco e Alagoas, que já existia antes da invasão flamenga e zombara de numerosas e repetidas tropas contra ele mandadas. Ficou assim livre todo o território entre as matas do cabo de Santo Agostinho e Porto Calvo.

Muitos dos paulistas empregados nas guerras do Norte não tornaram mais a S. Paulo, e preferiram a vida de grandes proprietários nas terras adquiridas por suas armas: de bandeirantes, isto é despovoadores, passaram a conquistadores, formando estabelecimentos fixos. Ainda antes do descobrimento das minas sabemos que nas ribeiras do rio das Velhas e do S. Francisco havia mais de cem famílias paulistas, entregues à criação de gado.

Conhecemos mal, para ajuizar dela, a vida levada em São Paulo pelos bandeirantes recolhidos aos lares, pela gente rica e poderosa. O seguinte trecho de Pedro Taques só em parte supre a lacuna, pois refere-se a época posterior às minas, o que altera em muito a situação:

Na casa de Guilherme Pompeu de Almeida, celebrava-se anualmente a festa de 8 de dezembro com um oitavário de festa de missas cantadas, sacramento exposto e sermão a vários santos de sua especial devoção e se concluía o oitavário com um aniversário pelas almas do purgatório, com ofício de nove lições, missa cantada e sermão para excitar a devoção dos fiéis ouvintes. De São Paulo concorria a maior parte da nobreza com os religiosos de maior autoridade das quatro comunidades, Companhia de Jesus, Carmo, São Bento e São Francisco, e os clérigos de maior graduação. Era a casa do Dr. Guilherme Pompeu naqueles dias uma populosa vila ou corte pela assistência e concurso dos hóspedes. Para a grandeza do tratamento da casa deste herói paulista, basta saber-se que fazia paramentar cem camas, cada uma com cortinado próprio, lençóis finos de bretanha, guarnecidos de rendas, e com uma bacia de prata debaixo de cada uma das ditas cem camas, sem pedir-se nada emprestado. Tinha, na entrada de sua fazenda da Araçariguama, um pórtico, do qual até as casas mediava um plano de 500 passos, todo murado, cujo terreno servia de pátio à igreja ou capela da Conceição.

Neste portão ficavam todos os criados dos hóspedes, que ali se apeavam, largando esporas e outros trastes com que vinham de cavalo, e tudo ficava entregue a criados, escravos, que para este político ministério os tinha bem disciplinados.

Entrava o hóspede, ou fosse um, ou muitos em número, e nunca mais nos dias que se demoravam, ainda que fossem de uma semana ou de um mês, não tinham nenhum dos hóspedes notícia alguma dos seus escravos, cavalos e trastes. Quando porém qualquer dos hóspedes se despedia, ou fosse um, quinze ou muitos ao mesmo tempo, chegando ao portão cada um achava o seu cavalo com os mesmo jaezes, em que tinha vindo montado, as mesmas esporas, e os seus trastes todos, sem que a multidão da gente produzisse a menor confusão na advertência daqueles criados, que para isto estavam destinados. Os cavalos recolhiam-se às cavalariças, onde tinham todo o bom penso de herva e milho, que é o que se dá diariamente no Brasil aos cavalos, principalmente na capitania de São Paulo... Esta advertência era uma das ações de que os hóspedes se aturdiam, por observarem que nunca jamais, entre a multidão de várias pessoas que diàriamente concorriam a visitar e obsequiar dias e dias ao Dr. Guilherme Pompeu de Almeida, se experimentava a menor falta, nem ainda uma só troca de trastes a trastes. Foi tão profusa a mesa do Dr. Guilherme Pompeu, que nela as iguarias de várias viandas se praticava com tal advertência, que se acabada a mesa, passadas algumas horas, chegassem hóspedes não houvesse para banqueteá-los a menor falta.

Por esta razão estava a ucharia sempre pronta. A abundância de trigo nesta casa foi tanta que todos os dias se fazia pão, de sorte que para o seguinte já não servia o que tinha sobrado do antecedente; o vinho era primoroso de uma grande vinha que com acerto se cultivava e suposto o consumo era sem miséria, sempre o vinho sobrava de ano a ano.

A vida do povo comum dizia mal com estes esplendores: a canjica, alimento da maioria da população, dispensava sal, porque este ingrediente não chegava para todos.

Os paulistas não se limitaram a passar de bandeirantes a conquistadores. Houve sempre alguma mineração em Iguape e Paranaguá: 
em maior número ainda, entregaram-se a pesquisas minerais a partir da era de 1670, depois que o monarca português apelou para seu brios. Antes da grande dispersão provocada pelos descobertos auríferos, a população grupava-se nas margens do Tietê e nas do Paraíba. Na ribeira do Tietê, Mogi das Cruzes, Parnaíba, Itu, Sorocaba; na do Paraíba, Jacareí, Taubaté, Guaratinguetá precedem os descobertos. A maior densidade provàvelmente notava-se no Paraíba, cujo vale estreitado à direita pela serra do Mar, à esquerda pela da Mantiqueira, produzia o efeito de condensador. Entretanto, a abundância de vilas não importa forçosamente população considerável. Em terras de donatários deviam facilitar as fundações o orgulho de poder juntar ao próprio nome o título de senhor de tais e tais vilas e o interesse de nomear tabeliães, etc.

Já neste tempo, Piratininga não se impunha como entrada única do planalto: formaram-se grupos conjugados do sertão e da marinha: Parati e Taubaté; S. Vicente, Santos, São Paulo, Mogi e quiçá Jacareí que, pelo menos mais tarde, possuiu ligação direta com o litoral; Iguape, Paranaguá, São Francisco e Curitiba: esta última, aparentemente destinada a situação preponderante, atraiu pouca população, e medrou precàriamente enquanto não lhe deu vida o comércio de trânsito, principalmente de muares, procedentes do Sul. 1690

Um escritor anônimo dizia a respeito dos paulistas pouco depois de

Sua Majestade podia se valer dos homens de São Paulo, fazendo-lhes honras e mercês, que as honras e os interesses facilitam os homens a todo o perigo, porque são homens capazes para penetrar todos os sertões, por onde andam continuamente sem mais sustento que caças do mato, bichos, cobras, lagartos, frutas bravas e raízes de vários paus, e não lhes é molesto andarem pelos sertões anos e anos, pelo hábito que têm feito daquela vida. E suposto que estes paulistas, por alguns casos sucedidos de uns para com outros, sejam tidos por insolentes, ninguém lhes pode negar que o sertão todo que temos povoado neste Brasil eles o conquistaram do gentio bravo que tinha destruído e assolado as vilas de Cairu, Boipeba, Camamu, Jaguaripe, Maragogipe e Peruaçu no tempo do governador Afonso Furtado de Mendonça, o que não puderam fazer os mais governadores antecedentes por mais diligências que fizeram para isso.
Também se lhes não pode negar que foram os conquistadores dos Palmares de Pernambuco, e também se podem desenganar que sem os paulistas com seu gentio nunca se há de conquistar o gentio bravo que se tem levantado no Ceará, no Rio Grande e no sertão da Paraíba e Pernambuco, porque o gentio bravo por serras, por penhas, por matos, por catinga só com o gentio manso se há de conquistar e não com algum outro poder, e dos paulistas se deve valer Sua Majestade para a conquista de suas terras.

$$
* * *
$$

Alexandre de Moura deixou Jerônimo de Albuquerque por capitãomor do Maranhão; da capitania subordinada de Cumá encarregou Martim Soares Moreno; a do Pará, confiada a Francisco Caldeira de Castelo Branco, ficaria independente, para evitar novos atritos entre os recentes rivais. Capitão de entradas elegeu Bento Maciel Parente, reinol criado em Pernambuco, que estivera nas guerras da Paraíba e Rio Grande, andara na jornada de salitre na Bahia, acompanhara d. Francisco de Sousa a São Vicente, e lá assistira um triênio empenhado em minas e bandeiras, outro de sargento-mor em cinco vilas do Sul.

Faltavam a Jerônimo de Albuquerque alguns requisitos para governar bem, na opinião insuspeita de Gaspar de Sousa; acusações lhe fizeram, bem graves se forem verdadeiras; algumas das recomendações de Alexandre de Moura parece ter descurado; mostrou-se mais próprio aos rompantes da guerra que às artes da paz. Faleceu em fevereiro de 1618 legando o cargo a seu filho Antônio de Albuquerque, assessorado por Bento Maciel e Diogo da Costa Machado. O jovem de vinte e dois anos desprezou os limites postos pelo pai à sua autoridade; quando, havendo preso aquele, o governador geral impôs-lhe a assistência do segundo, preferiu retirar-se para o reino. Substituiu-o no mando desde abril de 1619 Diogo Machado; de suas mãos recebeu-o Antônio Muniz Barreiros em maio de 1622, e ocupou-o até agosto de 1626.

Durante esta primeira década, Bento Maciel fez diversas entradas aos rios Mearim e Pindaré, seguindo os exemplos e processos dos bandeirantes e construiu um forte no Itapicuru, bastante acima da barra. Outras entradas fez Francisco de Azevedo, o primeiro a penetrar nos sertões de Turi e Gurupi. O gentio de Cumá insurgiu-se apenas Martim Soares saiu para o Reino, urgido por antigas enfermidades. Sob seu sucessor Matias, irmão de 
Antônio de Albuquerque, a guarnição portuguesa foi quase toda trucidada, e o levante estendeu-se quase à ponta de Saparará. A devastação nos índios foi enorme; os jesuítas Manuel Gomes e Diogo Nunes, convictos da inutilidade de seus esforços em favor dos indígenas, procuraram as Índias Ocidentais; Fr. Cristóvão de Lisboa, chefe dos capuchos, viu desrespeitadas as leis mais explícitas e até as censuras.

No governo de Diogo da Costa Machado chegaram a São Luís algumas centenas de açorianos, engajados para povoadores. Nada encontraram feito para recebê-los, e padeceram as maiores privações e misérias. A imigração, iniciada sob fagueiras esperanças, não recobrou o alento originário com o livro de propaganda de Simão Estaço da Silveira.

No empenho de criar engenhos, o governo geral contratou a construção de dois ou três com Antônio Barreiros; a nomeação do filho para capitão-mor do Maranhão visava facilitar a execução do trato. Um engenho construiu Bento Maciel. A terra prestava-se bem à cultura da cana; braços podiam fornecer os índios sujeitos às administrações usadas nas colônias espanholas e transplantadas por Bento Maciel; a dificuldade grande pendia dos transportes. Ficava próximo Pernambuco, o maior mercado do país, mas só se navegava para lá durante certa parte do ano, nas monções; a viagem terrestre pela costa, feita na estação das águas, para escapar aos tormentos sofridos por Pedro Coelho quando tentou colonizar o Ceará, apenas poderia servir à passagem de escravos. Parece ter servido efetivamente: fala um contemporâneo na "grande quantidade de patacões que os moradores do Maranhão houveram pelo comércio com os de Pernambuco, enviando-lhes de quando em quando escravos."

Além da cana plantava-se algodão e fumo; o fio e o pano de algodão correram como moeda. Os navios partiam para o reino em agosto ou setembro.

As dificuldades de comunicações marítimas entre o Maranhão e o resto do Brasil sugeriram a ideia de criar ali um estado independente. Isto se ordenou em 1621. Começava no Ceará, próximo do cabo de São Roque, e ia à fronteira setentrional, ainda indefinida, do Pará. Francisco Coelho de Carvalho, primeiro governador, aportou a Pernambuco ao tempo da invasão holandesa na Bahia. Deteve-o ali Matias de Albuquerque; depois, sob vários pretextos, foi se deixando ficar; só em agosto de 1626 chegou a seu destino, levando Manuel de Sousa de Sá, capitão-mor do Pará, declarado agora dependente do Estado do Maranhão.

Na capitania do Pará, Francisco Caldeira de Castelo Branco, recebido amigavelmente pelo gentio, apanhara o primeiro pretexto para guerreá-lo. A imensidade das águas inspirou-lhe a adaptação de um suplício mediável, que devia parecer novo e terrível aos rudes filhos da natureza: amarrava o condenado a diversas canoas, mandava remar em sentidos opostos, até os membros despregarem do tronco. Seu gênio rixento, já revelado em presença dos franceses, malquistou-o com os compatriotas; cansados de aturá-lo, depuseram-no, meteram-no a ferros, e substituiram-no por Baltasar Rodrigues em novembro de 1618. Nem assim arrefeceu a sanha dos índios; o movimento de Cumá soldou-se ao do Pará. Teve-se de reclamar auxílio de Pernambuco; vieram socorros sob as ordens de Jerônimo Fragoso, nomeado capitão-mor por d. Luís de Sousa, governador geral, com ordem, logo cumprida, de mandar presos Castelo Branco, Rodrigues e outros cabecilhas. Castelo Branco morreu na prisão do Limoeiro, em Lisboa.

Bento Maciel, que fora a Pernambuco depois das questões com Antônio de Albuquerque, voltou com gente nova recrutada nas duas capitanias vizinhas, e repetiu com maior fúria suas costumadas façanhas. De Tapuitapera até dentro do Amazonas tamanhas foram suas devastações que Jerônimo Fragoso intimou-lhe cessasse as hostilidades; ele, porém, desrespeitou a intimação porque, sendo o comandante da guerra por investidura do governador geral, não estava subordinado ao capitão-mor do Pará. Fragoso faleceu logo; houve diversos pretendentes à sucessão; por fim saiu nomeado Bento Maciel, que abriu um caminho terrestre para o Maranhão, ligando talvez o rio Capim ao Pindaré, como se tentou mais tarde, e governou quatro anos, até chegar Manuel de Sousa de Sá, em 1627.

Francisco Caldeira fora logo à chegada informado de viagens e fortalezas de ingleses e flamengos nas plagas amazônicas. No próprio ano da fundação de Belém, Pedro Teixeira aprisionou uma nau holandesa, cuja artilharia serviu a reforçar a do Presepe. Os ingleses preferiam a foz do rio e seu estabelecimento mais ocidental assentava no Cajari; os flamengos avançaram até o Xingu. Diversas expedições, em que se distinguiram Pedro Teixeira, Pedro da Costa Favela, Feliciano Coelho, Jácome Raimundo de Noronha tomaram navios, fizeram muitos prisioneiros e arrasaram um a um todos os fortes. No assalto ao forte inglês de Filipe, gaba-se Noronha de 
haver tomado quatro peças de artilharia grossas e roqueiras e muitas armas, com a morte de oitenta e três estrangeiros, o aprisionamento de treze, a destruição de todos os gentios confederados, "com que ficaram tão aterrorizados que nunca mais tiveram pazes com os estrangeiros".

A falta de índios amigos, fornecedores de fumo, algodão, urucu (anoto, em língua cariba) e outras drogas, bastaria a dissuadir os entrepolos de novos cometimentos. Veio ainda mais dificultá-los a fortaleza de Gurupá, estabelecida no local de um antigo forte holandês, no começo do delta amazônico, excelente posto de observação para todos os movimentos da margem esquerda, obra avançada e complemento precioso do forte de Presepe na margem direita. O último estabelecimento holandês de que temos notícia tomou-o Sebastião de Lucena em 1646, no Maiacaré, junto ao cabo do Norte; os ingleses já havia anos não apareciam. Ficou assim firmada a soberania de Portugal desde o cabo do Norte até a ponta de Saparará, e desassombrado de inimigos todo o baixo Amazonas.

No tempo de Francisco Coelho, foi dividido o Estado do Maranhão em várias capitanias hereditárias: as de Tapuitapera e Cametá couberam a um irmão e ao filho do governador, a de Caeté ou Gurupi a Álvaro de Sousa, filho de Gaspar de Sousa, que tantos serviços prestara à conquista; para si a metrópole reservou no Maranhão o território entre o Parnaíba e o Pindaré, no Pará as terras de Maracanã ao Tocantins. Mais tarde Bento Maciel obteve a capitania do cabo do Norte limitada pelos rios Vicente Pinzon ou Oiapoque, Amazonas e Paru, e Antônio de Sousa de Macedo a da ilha Marajó.

A penetração no Amazonas prosseguia lentamente: pela margem setentrional tratara-se apenas de eliminar os entrelopos; ao Sul a aldeia Maturu, na margem direita do Xingu, também chamado Parnaíba, durante algum tempo permaneceu o posto mais ocidental; ante as flechas envenenadas do gentio do Tapajós estacaram as entradas. A marcha precipitou-se a partir de 1637 com a chegada de dois leigos franciscanos vindos do pé dos Andes. Jácome de Noronha, que com certo atropelo de formas sucedera no governo por falecimento de Francisco Coelho de Carvalho, resolveu abrir relações com as dependências cisandinas de Castela. Pedro Teixeira, incumbido desta missão, partiu a 17 de outubro águas a riba do rio-mar, em 15 de agosto de 1638 alcançou o Paiamino, afluente do Napo, e seguiu para Quito. Depois de receber as ordens do vice- rei do Peru, regressou e chegou ao Pará em 12 de dezembro do ano seguinte. Já de volta, a 16 de março de 1639, na barra do Aguarico, tomou posse em nome da coroa de Portugal das terras que para o Oriente se estendiam até beira-mar. Bento Maciel, então governador do estado, recompensou estes e outros serviços durante mais de quatro lustros prestados por seu companheiro de armas, concedendo-lhe por três vidas a encomendação de trezentos casais de índios.

Mal suspeitava então o velho capitão de entradas os perigos que se avizinhavam. Desde de 1637, Gedeon Morris, flamengo preso em combate no Amazonas e lá conservado prisioneiro durante oito anos, lograra repatriar-se e chamava a atenção da câmara de Zelândia para a conquista do Maranhão. Tal conquista, alegava, traria a aquisição de mais de quatrocentas léguas de costa, ocupadas apenas por mil e quatrocentos a mil e quinhentos portugueses, e quarenta mil índios; os índios estavam sujeitos mais por medo que por afeição, os portugueses com as forças disseminadas, os soldados descontentes e rebeldes pelo desgoverno e falta de pagamento, os fortes pouco defensáveis; os índios considerariam os flamengos como libertadores. A Companhia das Índias Ocidentais se apossaria de belos açúcares, fumos, algodão, laranjas, anil, tintas, óleos e bálsamos, gengibres, gomas e várias sortes de excelentes madeiras. Poderia vender escravos para Pernambuco "como os portugueses faziam outrora, antes de começar a guerra naquela capitania, e este era o seu maior negócio".

Quando Morris expunha estas ideias em Middelburg, ocorria na colônia um fato próprio a facilitar-lhes a execução. Atendendo a repetidos chamados do gentio cearense, a Companhia mandou uma expedição que desembarcou no Mocuripe, e após brava mas inútil resistência da guarnição apossou-se do forte fundado por Martim Soares Moreno. Havia agora um ponto de apoio para as operações apregoadas como tão proveitosas: Gedeon Morris foi nomeado comandante do Ceará, onde descobriu as salinas do Ipanema, como que a preparar a avançada.

A notícia da viagem de Pedro Teixeira, apenas divulgada, ainda mais confirmou-o em suas traças e aspirações. A todas as vantagens apresentadas, a conquista do Maranhão juntava ainda a da contiguidade com as terras do Peru, e seria portanto o mais terrível golpe contra as possessões espanholas, insistia novamente Gedeon. Não foi compreendido. Nassau e as autoridades superiores preocupavam-se antes com a conquista 
de Buenos Aires e do Chile, procurando longe o que lhes acenava de tão perto. Só mais tarde atenderam a suas incitações; em novembro de 1641 apresentou-se uma esquadra holandesa na baía de São Marcos.

Vigorava o estado esquisito criado pela política hesitante de d. João IV. Não havia guerra, pois fora decidida na Europa uma aliança ofensiva e defensiva entre Portugal e Holanda; não havia paz nas colônias, porque faltava a ratificação do tratado. Iludido ou decrépito ou aterrado, Bento Maciel entregou-se sem combater e a Companhia das Índias mais uma vez alargou seus domínios. Morris, que tomou parte na operação, ficou descontente com o modo de proceder de Nassau. Por que depois de tomada a ilha não passavam logo ao Pará? Por que não expulsavam os portugueses ricos deixando apenas os mais pobres como feitores? Onde se viu em todo o Brasil um português, quatro meses apenas depois de tomada a terra, embarcar por sua conta cem caixas de açúcar, como fez o provedor-mor Inácio do Rêgo, que se passou para as Índias? Que valia a posse do Maranhão sem a incorporação do Amazonas?

Enquanto dominaram, os flamengos houveram-se com a cobiça e a venalidade já correntes em Pernambuco. Entretanto, a população calava-se e parecia mesmo disposta a não reagir, se não fossem Antônio Muniz Barreiros, o antigo capitão-mor, e os jesuítas Benedito Amadeu e Lopo do Couto, este chegado em companhia de um coadjutor desde 1624. Impeliram a estes chefes insurgentes sobretudo considerações religiosas: o holandês era o herege e a fé católica perigava. O movimento começou no Itapicuru, libertado em poucos dias, e passou à ilha. Aqui a resistência foi maior: vieram socorros de Pernambuco para o flamengo, também os nossos receberam-nos do Pará, mas a falta de armas e munições obrigou-os a passarem para a capitania de Tapuitapera, no continente. Mais tarde, chegados recursos da Bahia, acometeram novamente a obra libertadora. A Teixeira de Melo, sucessor de Barreiros, morto em consequência de ferimentos, coube a glória de restaurar S. Luís em 1643. O exemplo do Maranhão propagou-se a Ceará, onde os índios trucidaram os holandeses, que entretanto voltaram mais tarde e se mantiveram até 1654. Também produziu impressão em Pernambuco, e alentou os anhelos patrióticos ainda desconexos, apontando um exemplo a seguir.

Nos anos seguintes o fato mais notável foi a introdução dos jesuítas. A Alexandre de Moura acompanharam dois, mas retiraram-se, reconhecendo a inutilidade de seus esforços na defesa dos índios. Luís Figueira, vindo com Antônio Barreiros, logrou apagar as prevenções dos colonos, limitando e encobrindo a sua ação, e depois de algum tempo recolheu-se à Europa. Lopo do Couto, além de isolado e portanto impotente, soube conquistar as simpatias no ardor da reconquista, de que foi a alma. Figueira, que desde 1638 preparava uma missão no além mar, afinal com muitos sócios partiu do reino mais Pedro de Albuquerque, nomeado sucessor de Bento Maciel. Por estarem ainda os holandeses senhores de $\mathrm{S}$. Luís, passaram ao Pará; junto à baía do Sol, Figueira e a maior parte dos companheiros afogaram-se ou foram mortos pelos índios, em junho de 643. Os sobreviventes pouco puderam fazer no Maranhão para onde se transportaram apenas as condições o permitiram; logo trucidaram-nos selvagens de Itapecuru. Em 1649 não havia mais um só padre da Companhia de Jesus em todo o Estado.

Entretanto, na Europa movia-se o padre Antônio Vieira, grande valido de dom João IV e um dos maiores escritores da língua. Pupilo de Fernão Cardim, colhera dos lábios deste amigo de Anchieta a história das primeiras missões, e a carreira de missionário formara uma das primeiras aspirações de sua alma ambiciosa. Mandado para o Reino quando se divulgou na Bahia a notícia da independência de Portugal, passara dez anos em terras europeias por vontade da Companhia ou insistência do rei, triunfando na tribuna sagrada, ajudando as mais espinhosas negociações diplomáticas, engenhando combinações financeiras como a da Companhia do Comércio, tão útil na guerra pela libertação de Pernambuco, influindo nos conselhos da coroa, dando ideias e defendendo as próprias ou alheias, estas principalmente, com uma abundância de expressões, uma sutileza de raciocínios, um bisantinismo de argumentos, uma fertilidade de distinções verdadeiramente admiráveis. Um dia apareceu-lhe o vácuo de todas estas pompas, invadiu-o a saudade da primeira infância e da segunda pátria e aspirou missionar no Maranhão.

Em setembro de 1652 partiram adiante nove missionários, trazendo por superior o padre Francisco Veloso: dois destes continuaram a viagem para o Pará, onde fundaram casa. Em seguida à primeira leva embarcou no Tejo o padre Vieira acompanhado de outros três jesuítas, que a 16 de janeiro de 1653, véspera de S. Antão, fundearam diante da capital do estado. Afinal chegavam defensores aos índios. Para que narrar esta história? Com os índios só havia duas políticas racionais: ou deixá-los 
aprisionar à vontade como então se fazia, ou proibir expressamente toda e qualquer escravidão. Nem uma das duas observaram quer o governo, quer os próprios jesuítas. Daí lutas contra os colonos cubiçosos, contra os governadores venais, contra padres e frades simoníacos, contra os legisladores incoerentes e a legislação instável, viagens pelo sertão e rios, travessias do oceano, sermões cáusticos, papéis sediciosos, expulsões e exprobrações, em suma uma série de tumultos trágicos ou burlescos. Mais interessa que tais historietas apresentar o organismo do estado cerca de 1662, tal qual o desseca o valente escritor em uma página memorável, ainda palpitante no pálido resumo aqui feito.

Os alicerces assentaram sobre sangue, com sangue se foi amassando e ligando o edifício e as pedras se desfazem, separam e arruínam. As terras se esterilizam; as plantações de mandioca não bastam para garantir o sustento; tem-se de buscar longe as madeiras e as terras de tabaco; minguaram a caça e a pesca; as povoações são muito distantes uma das outras e o trabalho de remar consome as forças da indiada. Não há açougue, nem ribeira, nem horta, nem tenda para vender as cousas usuais para o comer ordinário, nem ainda um arratel de açúcar, com se fazer na terra. No Pará, onde todos os caminhos são por água, não há uma canoa de aluguel. Para um homem ter o pão da terra há de ter roça, e para comer carne há de ter caçador, e para comer peixe pescador e para vestir roupa lavada lavadeira, e para ir à missa ou qualquer parte canoas e remeiros: os moradores de tal cabedal têm a mais de tudo isto costureiras, fiandeiras, rendeiras, teares e outros instrumentos e ofícios de mais fábrica, com que cada família vem a ser uma república.

Os povoadores primeiros foram gente pobre: soldados idos de Pernambuco, mal pagos a ponto de raros poderem calçar sapatos e meias; ilhéus nobres, mas gente necessitada, impelida à emigração pela procura de meios não existentes no arquipélago; soldados rotos e despedidos tomados na guerra e abandonados nas costas pelos holandeses; finalmente degradados.

Não guarda proporção com a população o número de frades: o Pará, com oitenta moradores, tem quatro conventos e sai dos moradores a paga de missas, ofícios e enterros, servem grande número de confrarias com grandes e involuntários gastos nas suas festas, porque em serem perguntados, se ouvem apregoar dos púlpitos e não basta o que grangeiam num ano para satisfazer os empenhos desta forçada devoção. Apenas a Companhia de Jesus não pesa sobre a gente, porque a renda concedida pela fazenda real a põe a coberto das necessidades.

As drogas do estado baixaram de preço, e mal bastam para pagar os fretes, em compensação os gêneros vindos da Europa vendem-se por preços excessivos. Dominam a ociosidade, a preguiça e o luxo: grassa o alcoolismo; só na cidade do Pará gastam anualmente quinze mil cruzados em aguardente da terra, sem falar na que vai do reino. Os governadores e oficiais de fazenda pagam-se em primeiro lugar, pouco deixando para os vigários e soldados; confiam os melhores ofícios aos criados; prendem, processam, recrutam, atravessam os gêneros.

Finalmente os índios, por sua natural fraqueza e pelo ócio, descanso e liberdade em que se criam, não são capazes de aturar por muito tempo o trabalho em que os portugueses os fazem servir, principalmente das canas, engenhos e tabacos, sendo muitos os que por esta causa continuamente estão morrendo; e como nas suas vidas consiste toda a riqueza e remédios dos moradores, é mui ordinário virem a cair em pouco tempo em grande pobreza os que se tinham por mais ricos e afazendados, porque a fazenda não consiste nas terras que são comuns senão nos frutos da indústria com que cada um as fabrica e de que são os únicos instrumentos os braços dos índios. - Até aqui Antônio Vieira, com esta vívida descrição da economia naturista.

Excetuando a de Bartolomeu Barreiros de Ataíde ao rio de Ouro, isto é, às terras de que Pedro Teixeira tomara posse em nome da coroa de Portugal, e a de João Betencourt Muniz contra os Anibás do Jari, as expedições tinham de preferência procurado a margem direita do Amazonas. Em 1663 Antônio Arnau Vilela dirigiu-se à outra margem e foi pouco feliz numa entrada do rio Urubu; a vingá-lo saiu Pedro da Costa Favela, que matou setecentos, aprisionou quatrocentos índios dos Guaneenas e Caboquenas, queimou trezentas aldeias. Atrás destes vieram outros, atraídos pela densidade da indiada. Logo em seguida começou a ser frequentado o rio Negro e finalmente o Branco. A fortaleza da barra do rio Negro, nas proximidades da atual cidade de Manaus, ponto de partida para este movimento de penetração, foi fundada logo depois.

No ano de 1693 foram determinados os territórios em que cada uma das ordens poderia estabelecer missões: aos jesuítas concedeu-se a margem 
meridional do Amazonas; aos franciscanos as terras do cabo do Norte até o rio Urubu; aos carmelitas coube o rio Negro.

Entrementes os jesuítas espanhóis no seu ardor de catequizar foram descendo o Solimões, como os do Paraguai procuraram o Paranapanema, Ivaí, Igyaçu e Uruguai. Samuel Fritz, natural da Boêmia, atraiu ao grêmio da igreja diversas tribos de línguas travadas, e os Cambebas ou Omagoas da língua geral, missionando até o Juruá ou talvez mais a Este. Motivos de saúde levaram-no ao Pará em setembro de 1689, onde sob vários pretextos o detiveram cerca de dois anos. Na volta, apesar de suas excusas, deram-lhe uma escolta para acompanhá-lo às reduções e, lá chegado, o oficial comandante protestou pertencerem a Portugal as terras que se estendiam até o rio Napo. Enquanto o apóstolo dos Mainas se dirigia a Lima, no intuito de avisar da próxima usurpação ao vice-rei do Peru, que não quis tomar providências, desde 1695 se discutia no Pará e em Lisboa a ideia de aumentar o domínio português por aqueles lados. Forneceu ensejo próprio o caso da sucessão da Espanha. Inácio Corrêa de Oliveira expulsou os jesuítas castelhanos do Solimões. Assim a guerra entre as duas coroas produziu ao Norte os mesmos efeitos que de sua união resultaram em Guairá, Uruguai e Tape. A estas invasões e às seguintes uniram-se os frades do Carmo, dignos confrades dos capuchos das bandeiras meridionais. Nestas missões aprenderam os invasores o emprego do caucho.

As entradas pelos afluentes da margem direita iam também continuando: em 1669 Gonçalo Pires e Manuel Brandão descobrem cravo, canela e castanha no Tocantins; em 1716 João de Barros Guerra derrota os Torás no Madeira; em 1720 marcha uma expedição contra os Juínas do Juruá; em 1724 Francisco de Melo Palheta sobe o Madeira até as aldeias espanholas. Com o descobrimento das minas, procura-se chegar a elas pelos afluentes meridionais. Mais de uma das tentativas foi bem sucedida e o Maranhão reclamou como pertencentes a seu distrito as minas de S. Félix e da Natividade, ribeirinhas do Tocantins. Desde a terceira década do século XVIII descem ao Amazonas mineiros de Goiás e Mato Grosso. Destas descidas a mais fértil em consequências foi a de Manuel Félix de Lima, que em 1742 navegou o Sararé, Guaporé, Mamoré, Madeira e alcançou o Maranhão. Quando o governador de Mato Grosso assentou a capital na margem do Guaporé apenas tirou a consequência do achamento deste caminho, que com o tempo se tornou o mais frequentado.
Lentamente a população ia crescendo, embora epidemias frequentes inutilizassem em poucos meses o progresso de anos. Como sinais evidentes de melhores condições, basta citar a fundação de um pesqueiro real em 1692 na ilha de Marajó, por Antônio de Albuquerque Coelho, e o desenvolvimento assumido pela criação de gado na mesma ilha, a partir dos primeiros anos do século seguinte. Na Páscoa de 1726 começou a funcionar um açougue em Belém. Quando La Condamine passou por Belém em 1743 a única moeda corrente eram grãos de cacau; desde maio de 1749 principiou a correr dinheiro amoedado de ouro, prata e cobre.

Em 1751, o Pará, a que agora estava subordinado o Maranhão, contava 9 freguesias e seis ermidas paroquiais, sete fortalezas, vinte e quatro engenhos de açúcar, quarenta e duas engenhocas de aguardente, sessenta e três aldeias de índios missionados. Muitas medidas concertou o governo para desenvolver a agricultura, mas só o conseguiu nas cercanias de Belém. O café, levado de Caiena por Francisco de Melo Palheta, pareceu despertar o torpor da população. Pouco tempo durou a experiência; preferiu-se a apanha de produtos florestais, cravo, canela, cacau, salsa, mais rendosos e criados à lei da natureza.

Os anos seguintes à partida de Antônio Vieira para a Europa em 1661 assinalam-se pela legislação caótica a respeito de aldeias, jurisdição espiritual e temporal, descimentos, salários e escravidão dos índios. Em 1680 uma lei proibiu que os índios fossem escravizados, única solução lógica e justa, se houvesse gente bastante honesta e bastante enérgica para fazê-la respeitada.

Para mitigar as queixas dos colonos criou-se uma companhia de comércio com o privilégio de vender certos gêneros de primeira necessidade, que compraria toda a produção do estado e forneceria escravos africanos, mais fortes e mais próprios para a pesada labuta agrícola.

Pouca repugnância provocou no Pará, cujos interesses, em partes divergentes, a distância resguardava; no Maranhão produziu grande alborôto. Foram expulsos os jesuítas, deposto e preso o capitão-mor, mandados procuradores à Corte para apresentar as queixas do povo e impetrar o perdão régio. Manuel Bequimão, reinol de origem teutônica, primeira figura da assuada, pôs-se à frente da governança. $\mathrm{O}$ movimento iniciado com tamanha valentia ficou estacionário; nem a fronteira capitania 
de Tapuitapera aderiu; dos aderentes da primeira hora, muitos foram-se esgueirando.

Nota-se agora o caso repetido tantas vezes em nossa história: depois do triunfo, obtido antes por desídia ou pusilanimidade do atacado que por habilidade ou fortaleza do atacante, e só depois do triunfo comprado tão barato, compreende-se que o fato importa consequências, e começa-se a indagação de quais poderão ser. Desta mandrice intelectual ou miopia política não se eximiu Bequimão. Quando apareceu na barra Gomes Freire de Andrada, nomeado governador do Estado e acompanhado de força armada para se fazer obedecido, veio-lhe a veleidade de opor-se ao desembarque. Nada previra, nada preparara, agora era tarde. O governador empossou-se do poder sem oposição.

Restava a esperança de ter trazido o perdão régio; mesmo este não veio. Prestes instaurou-se o processo, e sairam condenados à morte Manuel Bequimão, Jorge de Sampaio e Deiró. Este padeceu o suplício em efígie; os outros subiram ao patíbulo. Com os figurantes o governador mostrou benevolência: de bondoso e benévolo deixou tradição entre os governados. Por seu conselho aboliram-se a companhia e o estanco; a questão índia prosseguiu com os avanços, recuos e sobressaltos do costume.

Durante seu governo preocupou-o a questão máxima do Estado: achar comunicações com o Brasil, independente do capricho das monções, sobranceira à linha dos vaus à beira-mar.

Poucos anos antes Vital Maciel Parente, filho do velho prisioneiro dos flamengos, depois de derrotar ao Tremembés, desafrontando o caminho da praia para o Ceará, navegara muitas léguas pelo Parnaíba e reconhecera a direção meridional de seu curso. Deve manar daí a ideia da proximidade senão identidade entre o Parnaíba ou Paraguaçu e o São Francisco. Assim a questão apresentava-se com certa nitidez: a Bahia representava o objetivo e o Parnaíba o rumo a seguir.

João Velho do Vale incumbido de resolver o problema levou-o a bom termo; escreveu a mesma narrativa do descobrimento, entregue mais tarde a Gomes Freire, no Reino, livro hoje extraviado ou perdido, e muito importante para a etnografia e história pátria, a julgar pelas indicações ligeiras, fornecidas por Fr. Domingos Teixeira, biógrafo do governador:
Depois de dar em larga relação notícia exata dos sertões que penetrou, rios, e nações várias que os habitam, sinalando pelos graus as alturas do polo, mais gasto do trabalho, que dos anos, veio a acabar [João Velho do Vale] em benefício da pátria, com serviços maiores que a gratidão. Descansam suas cinzas em jazigo humilde na cidade de São Salvador, onde veio consumar com último termo seus trabalhos com mais honra que interesse.

Vale fez duas viagens. Na primeira chegou à serra de Ibiapaba, onde deixou três estradas; da segunda alcançou a Bahia, naturalmente partindo da mesma serra, o que indica traçado bastante oriental, talvez pelas ribeiras do Poti e contravertentes do rio São Francisco, Cabrobó, Ibó e Jeremoabo.

É impossível decidir se a esta ou a outra estrada se refere uma carta de Antônio Albuquerque, sucessor de Gomes Freire, escrita em julho de 1694 e entregue na Bahia a d. João de Lencastro, governador geral, em 19 de abril do ano seguinte. Dois dias depois chegava à mesma cidade o sargento-mor Francisco dos Santos com quatro soldados e vinte índios, que tinham acabado de descobrir o caminho, trazendo uma carta de Antônio de Albuquerque datada de 15 de dezembro. Para retribuir a fineza e ver se podia encurtar o caminho, o governador geral mandou o capitão André Lopes ao Maranhão, com carta para Antônio de Albuquerque datada de 21 de maio. André Lopes alcançou a capital do Estado em novembro mas teve de esperar pela volta de Antônio de Albuquerque, ido ao Pará. Com resposta de 15 de março de 1696 estava na Bahia em 22 de setembro.

$\mathrm{O}$ trecho mais difícil a vencer ficava no Maranhão pròpriamente dito: nos rios Piauí e Canindé, nas ribeiras do Ceará, a uma e outra margem do São Francisco já abundavam fazendas de gado e deviam existir numerosas vias de comunicação. Com o gado desta procedência povoaramse os sertões de Pastos Bons, cujas transações durante algum tempo se fizeram só com a Bahia, exatamente como as de Pernambuco a montante de Paulo Afonso.

Mais tarde o padre Malagrida levou a catequese até o rio Codó; seu sucessor João Ferreira fundou as Aldeias Altas, hoje Caxias. Conhecida a pequena distância neste trecho entre o Itapecuru e o Parnaíba começou a ser preferida esta passagem. Já em 1747 dela se servia d. Manuel da Cruz, trasladado do sólio do Maranhão para o de Mariana. 
Maranhão começou a decair desde ou antes do governo de Gomes Freire, e explica-se o fato pelo abandono da agricultura, devido a produtos florestais semelhantes aos do Pará. Ao cravo, à canela, à castanha sucumbiram os engenhos. em 1703,

"Erigiram cerca de cinquenta engenhos", escrevia um contemporâneo

que fabricaram enquanto se não descobriu o cravo e cacau, total ruína daqueles homens, como causa de ócio com que todos deixaram perder a fábrica de tabaco e açúcar em que se iam aumentando... Terrível é a dificuldade que têm os senhores de engenho em acomodar a conveniência de seus lavradores, em quem também é impraticável o querer lavrar canas; uns e outros confessam esta pela melhor conveniência, clamando que por falta dela estão miseráveis e que quando dela usavam viviam prósperos; porém, não há remédio em ajustarem-se; os lavradores com justa causa queixosos e teimosos com notável sem-razão; os senhores de engenho tiranos de suas próprias consciências: esta desunião é capaz de impedir as fábrica dos engenhos e não é o menos outro erro a que aqueles homens estão amarrados, querendo fabricar tudo o que gastam, como são lenhas, cinzas, azeites, farinhas, tabuados e canoas, em cuja fábrica divertindo a gente dos engenhos lhes não fica lugar de fabricar açúcar.

Informando este papel, acrescentava Antônio de Albuquerque: como estejam só com o sentido no sertão, feitos hidrópicos do gentio que só apetecem e procuram por único remédio, não tratam de se disporem a outro algum meneio.

Em 1751 a capitania contava oito freguesias, cinco engenhos de açúcar, duzentas e três fazendas a criar gado, das quais quarenta e quatro em Pastos Bons e trinta e cinco em Aldeias Altas.

As questões de limites com a Espanha, não menos que a importância crescente do Pará, foram causa da metrópole declarar-lhe subordinado o Maranhão e transferir para a bacia do Amazonas a capital do Estado. Breve, porém, graças à cultura do algodão e do arroz, à introdução de escravos africanos e à intervenção de nova companhia de comércio, abriu-se uma era de prosperidade relativa, muito inferior entretanto a seus imensos recursos naturais.

$$
* * *
$$

Os engenhos de açúcar, as roças de fumo e mantimentos cabiam dentro de uma área traçada pelo custo de transporte dos produtos. Além de certo raio vegetava-se indefinitivamente, a prosperidade real nunca bafejaria o proprietário. Com a economia naturista, o equívoco podia prolongar-se por muito tempo, mas por fim patenteava-se que só próximo do mar ou no pequeno trecho dos rios navegáveis graças à ausência de corredeiras e saltos, a labuta agrícola encontrava remuneração satisfatória. Queixam-se os primeiros cronistas de andarem os contemporâneos arranhando a areia das costas como caranguejos, em vez de atirarem-se ao interior. Fazê-lo seria fácil em São Paulo, onde a caçada humana e desumana atraía e ocupava a atividade geral, na Amazônia toda cortada de rios caudalosos e desimpedidos, com preciosos produtos vegetais, extraídos sem cultura. Na outras zonas interiores o problema pedia solução diversa.

A solução foi o gado vacum.

O gado vacum dispensava a proximidade da praia, pois como as vítimas dos bandeirantes a si próprio transportava das maiores distâncias, e ainda com mais comodidade; dava-se bem nas regiões impróprias ao cultivo da cana, quer pela ingratidão do solo, quer pela pobreza das matas sem as quais as fornalhas não podiam laborar; pedia pessoal diminuto, sem traquejamento especial, consideração de alta valia num país de população rala; quase abolia capitais, capital fixo e circulante a um tempo, multiplicando-se sem interstício, fornecia alimentação constante, superior aos mariscos, aos peixes e outros bichos de terra e água, usados na marinha. De tudo pagava-se apenas em sal; forneciam suficiente sal os numerosos barreiros dos sertões.

A criação de gado primeiro se desenvolveu nas cercanias das cidade do Salvador; a conquista de Sergipe estendeu-se à margem direita do São Francisco. Na outra margem veio dar menos forte e menos acelerado o movimento idêntico partido de Pernambuco. Ao romper a guerra holandesa estavam inçadas de gado as duas bandas do rio em seu curso inferior. Nem por outro motivo as incorporou Maurício de Nassau ao território da Companhia das Índias Ocidentais, e os patriotas da liberdade divina com tanto afinco as defenderam. 
Foi o gado acompanhando o curso do São Francisco. O povoado maior, a Bahia, atraiu todo o da margem meridional, que para lá ia por um caminho paralelo à praia, limitado pela linha dos vaus.

Mais tarde, à medida que a criação se afastou do litoral, outros caminhos se tornaram necessários. Um dos mais antigos passava por Pombal no Itapecuru, Jeremoabo no Vasabarris, e atingindo o São Francisco acima da região encachoeirada, chamou o gado da outra margem. Esta, pertencente a Pernambuco por todos os títulos, ficou de fato baiana, foi povoado por baianos, e como o chapadão do São Francisco se estreita depois da grande volta, onde ao contrário atinge sua maior expansão o do Parnaíba, consumou-se aqui a passagem de um para o outro, e encontraramse os baianos com a gente vinda do Maranhão. O riacho do Terra Nova e o do Brígida facilitaram a marcha para o Ceará. Pelo do Pontal e pela serra dos Dois Irmãos passaram os caminhos do Piauí. Nem o Parnaíba teve poder para conter a onda invasora: Pastos Bons foi povoado por baianos, e até meados do século XVIII teve comunicações exclusivamente com a Bahia.

$\mathrm{Na}$ margem pernambucana do rio S. Francisco possuía duzentas e sessenta léguas de testada a casa da Torre, fundada por Garcia d'Ávilla, protegido de Tomé de Sousa, a qual entre o S. Francisco e o Parnaíba senhoreava mais oitenta léguas. Para adquirir estas propriedades imensas, gastou apenas papel e tinta em requerimentos de sesmarias. Como seus gados não davam para encher tamanhas extensões, arrendava sítios, geralmente de uma légua, à razão de $10 \$$ por ano, no princípio do século XVIII. Um de tais rendeiros, Domingos Afonso, por alcunha o Sertão, partindo de um dos muitos sobrados existentes no São Francisco, aos quais se dá este nome por causa de vagamente semelharem um edifício, fundou numerosas e importantes fazendas nos rios Piauí e Canindé, legadas por sua morte à Companhia de Jesus, a quem a coroa as confiscou em proveito próprio, por ocasião de suprimir a Ordem.

Por esta margem do São Francisco existiam numerosas tribos indígenas, a maioria pertencente ao tronco cariri, algumas caribas como os Pimenteiras, e até tupis como os Amoipiras. Com elas houve guerras, ou por não quererem ceder pacificamente as suas terras, ou por pretenderem desfrutar os gados contra a vontade dos donos. Estes conflitos foram menos sanguinolentos que os antigos: a criação de gado não precisava de tantos braços como a lavoura, nem reclamava o mesmo esforço, nem provocava a mesma repugnância; além disso abundavam terras devolutas para onde os índios podiam emigrar. Entretanto, muitos foram escravizados, refugiaramse outros em aldeias dirigidas por missionários, acostaram-se outros à sombra de homens poderosos, cujas lutas esposaram e cujos ódios serviram.

Resistiram bastante os índios do Pajeú, mas em tempo de d. João de Lencastro e por sua ordem Manuel de Araujo de Carvalho atacou-os. Simultaneamente penetrava da Paraíba Teodósio de Oliveira Ledo. Graças aos esforços dos dois, ficaram pacificados os sertões de Pajeú, Piancó e Piranhas. Parte deles abriu comunicações com Pernambuco, para onde mandava seus gados. Pajeú, apesar da proximidade, só fez isto em começos do século XIX; até então gravitava para a Bahia.

Ao compasso do afastamento do gado, novas passagens e novos caminhos iam sendo trilhados. Basta citar o de Jacobinas e a passagem do Juazeiro, pelo qual pautou-se uma estrada de ferro. Com o crescimento de Cachoeira e o impulso do plantio de fumo, abriu-se um ramal importante em busca do baixo Paraguaçu.

A margem baiana do São Francisco criou gado em não menor quantidade, embora no terreno cortado de serras e nas matas litorâneas ou ribeirinhas se conservasse numerosa população indígena, sempre disposta a salteios. As bandeiras de Arzão e Estêvão Parente e outras enfraqueceram, mas não extinguiram a resistência do gentio, e anos depois guerreavam-se ainda nas cabeceiras do rio de Contas, Pardo, etc. O grande proprietário desta banda chamava-se Antônio Guedes de Brito, com cento e sessenta léguas, contadas do morro do Chapéu até águas do rio das Velhas. Merecem também ser mencionados João Peixoto Viegas, que incorporou as terras do alto do Paraguaçu; Matias Cardoso e Fiqueira, conquistadores paulistas, estabelecidos em situações muito próprias a favorecerem o tráfego com $\mathrm{S}$. Paulo. Os caminhos destes lados entroncaram primeiramente nos que pela margem esquerda do S. Francisco demandavam o chapadão do Parnaíba; só mais tarde o Paraguaçu foi procurado desde o curso superior e seguido até Cacheira, perto da barra.

Os primeiros ocupadores do sertão passaram vida bem apertada; não eram os donos das sesmarias, mas escravos ou prepostos. Carne e leite havia em abundância, mas isto apenas. A farinha, único alimento em que o povo tem confiança, faltou-lhes a princípio por julgarem imprópria a terra à 
plantação da mandioca, não por defeito do solo, pela falta de chuva durante a maior parte do ano. O milho, a não ser verde, afugentava pelo penoso do preparo naqueles distritos estranhos ao uso do monjolo. As frutas mais silvestres, as qualidades de mel menos saborosas eram devoradas com avidez. Pode-se apanhar muitos fatos da vida daqueles sertanejos dizendo que atravessaram a época do couro. De couro era a porta das cabanas, o rude leito aplicado ao chão duro, e mais tarde a cama para os partos; de couro todas as cordas, a borracha para carregar água, o mocó ou alforge para levar comida, a maca para guardar roupa, a mochila para milhar cavalo, a peia para prendê-lo em viagem, as bainhas de faca, as broacas e surrões, a roupa de entrar no mato, os banguês para cortume ou para apurar sal; para os açudes, o material de aterro era levado em couros puxados por juntas de bois que calcavam a terra com seu peso; em couro pisava-se tabaco para o nariz.

Adquirida a terra para uma fazenda, o trabalho primeiro era acostumar o gado ao novo pasto, o que exigia algum tempo e bastante gente; depois ficava tudo entregue ao vaqueiro. A este cabia amansar e ferrar os bezerros, curá-los das bicheiras, queimar os campos alternadamente na estação apropriada, extinguir onças, cobras e morcegos, conhecer as malhadas escolhidas pelo gado para ruminar gregàriamente, abrir cacimbas e bebedouros. Para cumprir bem com seu ofício vaqueiral, escreve um observador, deixa poucas noites de dormir nos campos, ou a menos as madrugadas não o acham em casa, especialmente de inverno, sem atender às maiores trovoadas, porque nesta ocasião costuma nascer a maior parte de bezerros e pode nas malhadas observar o gado antes de espalhar-se ao romper do dia, como costumam, marcar as vacas que estão próximas a ser mães e trazê-las quase como à vista, para que parindo não escondam os filhos de forma que fiquem bravos ou morram de varejeiras.

Depois de quatro ou cinco anos de serviço, começava o vaqueiro a ser pago; de quatro crias cabia-lhe uma; podia assim fundar fazenda por sua conta. Desde começos do século XVIII, as sesmarias tinham sido limitadas ao máximo de três léguas separadas por uma devoluta. A gente dos sertões da Bahia, Pernambuco, Ceará, informa o autor anônimo do admirável Roteiro do Maranhão a Goiás, tem pelo exercício nas fazendas de gado tal inclinação que procura com empenhos ser nela ocupada, consistindo toda a sua maior felicidade em merecer algum dia o nome de vaqueiro. Vaqueiro, criador ou homem de fazenda, são títulos honoríficos entre eles.
As boiadas procuravam os maiores centros de população, isto é, as capitais da Bahia e Pernambuco.

Sobre as que iam para a Bahia escreve o seguinte André João Antonil, anagrama do benemérito jesuíta João Antônio Andreoni:

Constam as boiadas que ordinariamente vêm para a Bahia, de cem, cento e cinquenta, duzentas e trezentas cabeças de gado; e desta quase cada semana chegam algumas a Capoame, lugar distante da cidade oito léguas, aonde tem pasto e aonde os marchantes as compram: e em alguns tempos do ano há semanas em que cada dia chegam boiadas. Os que as trazem são brancos, mulatos e pretos, e também índios que com este trabalho procuram ter algum lucro. Guiam-se indo uns adiante cantando, para serem desta sorte seguidos do gado; e outros vêm atrás das reses tangendo-as e tendo cuidado que não saiam do caminho e se amontem. As jornadas são de quatro, cinco e seis léguas, conforme a comodidade dos pastos aonde hão de parar. Porém, aonde há falta de água, seguem o caminho de quinze, e vinte léguas, marchando de dia e de noite, com pouco descanso, até que achem paragem aonde possam parar. Nas passagens de alguns rios, um dos que guiam a boiada, pondo uma armação de boi na cabeça e nadando, mostra às reses o vau por onde hão de passar.

Por maior cuidado na condução das boiadas, transviavam-se algumas reses, outras por fracas ficavam incapazes de continuar a marcha. Contando com isso, alguns moradores se estabeleceram nos caminhos e por pouco preço compravam este gado depreciado que mais tarde cediam em boas condições. Além disso, faziam uma pequena lavoura, cujas sobras vendiam aos transeuntes; alguns, graças aos conhecimentos locais, melhoraram e encurtaram as estradas; fizeram açudes, plantaram canas, proporcionaram ao sertanejo uma de suas alegrias, a rapadura. No rio S. Francisco, desde a barra do Salitre até São Romão, descobriram-se jazidas de sal na detenção de três graus geográficos, que preparado com algum trabalho provou excelente. Graças a estas circunstâncias, formou-se no trajeto do gado uma população relativamente densa, tão densa como só houve igual depois de descobertas as minas, nas cercanias do Rio.

Perdeu assim os terrores a viagem do sertão, e cerca de 1690 havia antes motivos a aconselhá-la. Um contemporâneo muito bem informado fala no preço altíssimo dos gêneros estrangeiros, na depreciação dos frutos da terra, na menor feracidade do solo em consequência do cansaço, nas 
limitações impostas à cultura do tabaco, "gênero fabricado por pretos, por brancos, por forros, por cativos, por ricos, por pobres, de que todos em sua qualidade se alimentavam e vestiam", nos excessos do contrato do sal, na prepotência da magistratura, na dificuldade de cobrar dívidas, no desenvolvimento anormal da mão-morta.

Das fazendas, terras, lavouras e propriedades possuídas das religiões nem Sua Majestade tem tributos, nem subsídios, nem ainda dízimos, nem as misericórdias, nem os hospitais, nem as sés, matrizes e mais igrejas, nem as confrarias e irmandades, nem as pobres órfãs e viúvas têm esmola alguma; só são úteis às religiões que as possuem e não a outra pessoa alguma... Anualmente vão indo às religiões muitas propriedades, terras e fazendas, ou por compra, ou por deixa, ou por herança, ou por demanda de pretensões de sessenta, setenta, oitenta, noventa e cem anos, as quais em poder dos vassalos seculares eram sujeitas a dízimos, tributos e mais pensões e incorporadas em religiões logo ficam isentas, e o pior é que aquele tanto ou quanto que pagavam de fintas, tributos subsídios e outros impostos, tornam a cair sobre os miseráveis seculares.

Desvanecidos os terrores da viagem ao sertão, alguns homens mais resolutos levaram família para as fazendas, temporária ou definitivamente e as condições de vida melhoraram; casas sólidas, espaçosas, de alpendre hospitaleiro, currais de mourões por cima dos quais se podia passear, bolandeiras para o preparo da farinha, teares modestos para o fabrico de redes ou pano grosseiro, açudes, engenhocas para preparar a rapadura, capelas e até capelães, cavalos de estimação, negros africanos, não como fator econômico, mas como elemento de magnificência e fausto, apresentaram-se gradualmente como sinais de abastança.

Se a Bahia ocupava os sertões de dentro, escoavam-se para Pernambuco os sertões de fora, começando de Borborema e alcançando o Ceará, onde confluíam a corrente baiana e pernambucana. A estrada que partia da ribeira do Acaracu atravessava a do Jaguaribe, procurava o alto Piranhas e por Pombal, Patos, Campina Grande, bifurcava-se para o Paraíba e Capibaribe, avantajava-se a todas nesta região. Também no alto Piranhas confluiram o movimento baiano e o movimento pernambucano, como já fica indicado.

Sobre a extensão de terras ocupada pelo gado vacum oferece-nos dados positivos o maravilhoso Antonil-Andreoni:
Estende-se o sertão da Bahia até a barra do rio de S. Francisco, oitenta léguas por costa; e indo para o rio acima até a barra que chamam de Água-Grande, fica distante a Bahia da dita barra cento e quinze léguas; de Santunse cento e trinta léguas; de Rodelas, por dentro, oitenta léguas; das Jacobinas, noventa, e do Tucano cinquenta... Os currais da parte da Bahia estão postos na borda do rio de São Francisco, na do rio das Velhas, na do rio das Rãs, na do rio Verde, na do rio Paramirim, na do rio Jacuípe, na do rio Ipojuca, na do rio Inhambupe, na do rio Itapicuru, na do rio Real, na do rio Vasabarris, na do rio Sergipe e de outros rios, em os quais, por informação tomada de vários, que correram este sertão, estão atualmente mais de quinhentos currais...

E posto que sejam muitos os currais da parte da Bahia chegam a muito maior número os de Pernambuco, cujo sertão se estende pela costa, desde a cidade de Olinda até o rio São Francisco, oitenta léguas; e continuando da barra do rio de São Francisco até a barra do rio Iguaçu, contam-se duzentas léguas. De Olinda para Oeste até o Piagui, freguesia de Nossa Senhora da Vitória, cento e sessenta léguas, e pela parte do Norte estende-se de Olinda até o Ceará-mirim, oitenta léguas, e daí até o Açu trinta e cinco, e até o Ceará Grande, oitenta; e por todas vem estender-se desde Olinda até esta parte, quase duzentas léguas..

Os currais desta parte hão de passar de oitocentos; e de todos estes vão boiadas para o Recife e Olinda e suas vilas e para o fornecimento das fábricas dos engenhos desde o rio de São Francisco até o rio Grande: tirando os que acima estão nomeados desde o Piagui, até a barra de Iguaçu e de Paranaguá e rio Preto; porque as boiadas destes rios vão quase todas para a Bahia, por lhes ficar melhor caminho pelas Jacobinas, por onde passam e descansam...

As [cabeças de gado] da parte da Bahia se tem por certo que passam de meio milhão, e mais de oitocentas mil hão de ser as da parte de Pernambuco, ainda que destas se aproveitam mais os da Bahia, para onde vão muitas boiadas, que os pernambucanos.

Muito tempo viveu esta gente entregue a si mesmo, sem figura de ordem nem de organização. Como eram católicos e a igreja à frequência dos sacramentos, naturalmente qualquer vigário ou algum mais animoso, mais zeloso ou mais cúpido saía de tempos em tempos a desobrigar as ovelhas remotas. Depois da instalação do arcebispado da Bahia, criaram-se freguesias no sertão, enormes, de oitenta, cem léguas e mais. Ali era 
cobrado o imposto meio civil meio eclesiástico do dízimo. Os dizimeiros que o arrematavam, depois de ter feito a experiência, preferiram deixar a outros o trabalho da arrecadação: um dos fazendeiros ou qualquer pessoa capaz do interior em seu nome ia pelos vizinhos recolher os bezerros dizimados, pois a paga realizava-se em gênero; depois de alguns anos, três ou quatro conforme a convenção, prestava contas: cabia-lhe pelo trabalho um quarto do gado, exatamente como aos vaqueiros.

A carta régia de 20 de janeiro de 1699, primeiro esforço para introduzir alguma ordem naquela massa amorfa, mandou criar nas freguesias do sertão juízes à semelhança dos de vintena, que saíam dos mais poderosos da terra, e em cada freguesia um capitão-mor e cabos de milícia obrigados a socorrer e ajudar os juízes. A resistência contra estes se equiparava à resistência contra os juízes de fora, e ficariam sequestrados os bens do réu até sentença final; as penas pecuniárias deveriam ser preferidas por não se poder facilmente executar as corporais. Ouvidores, corregedores eram obrigados a uma visita trienal. Se tais ordens foram cumpridas e nos arquivos de além-mar existirem relatórios das correções, nem um documento poderá nos ajudar tanto no estudo e conhecimento da vida sertaneja.

Os capitães-mores deixaram fama de violentos, arbitrários e cruéis; não eram, porém, incontratáveis e maior ou menor sempre encontraram oposição. Reinava respeito natural pela propriedade; ladrão era e ainda é hoje o mais afrontoso dos epítetos; a vida humana não inspirava o mesmo acatamento. Questões de terra, melindres de família, uma descortesia mesmo involuntária, coisas às vezes de insignificância inapreciável desfechavam em sangue. Por desgraça não se dava o encontro em campo aberto: por trás de um pau, por uma porta ou janela aberta descuidosamente, na passagem de algum lugar ermo ou sombrio lascava o tiro assassino, às vezes marcando o começo de longa série de assassinatos e vendetas. Com a economia naturista dominante, custava pouco ajuntar valentões e facinorosos, desafiando as autoridades e as leis. Para apossar-se destes régulos só havia dois recursos: a astúcia ou o auxílio de vizinhos. Além do sentimento de orgulho inspirado pela riqueza, pelo afastamento de autoridades eficazes, pela impunidade, a criação de gado teve um efeito, que repercutiu longamente. Graças a ela foi possível descobrir mina. Desde 1618 o autor dos Diálogos das Grandezas do Brasil dizia que o problema da mineração não consistia em encontrar metais, — estes existiam não restava dúvida, pois o Oriente é mais nobre que o Ocidente e portanto o Brasil mais opulento que o Peru; o problema verdadeiro consistia na dificuldade de alimentar os mineiros. E expunha um plano:

O primeiro que se devia fazer antes de bulir nelas, depois de estarem certos que eram de proveito, houvera de plantarem-se muitos mantimentos ao redor do sítio onde elas estão e como os houvesse em abundância tratar-se-ia da lavoura das minas; mas isto se faz pelo contrário, porque sem terem mantimento entenderam em tirar o ouro e como as minas estão muito pelo sertão os que vão levam de carreto o mantimento necessário e como se lhe acaba tornam-se e deixam a lavoura que tinham começado. E esta cuido que é a verdadeira causa de darem as ditas minas pouco de si.

O plano decorria da natureza das coisas e Fernão Dias Pais, sem nunca ter lido os Diálogos das Grandezas do Brasil, conservados inéditos até muito poucos anos, obedeceu-lhe na famosa jornadas das esmeraldas; seria suficiente enquanto os mineiros se limitassem a bandos mais ou menos numerosos, e a alimentação vegetal pudesse ser suprida com a caça e a pesca; depois do alborôto provocado pelos descobertos era indispensável recurso menos aleatório, e impunha-se a necessidade de gado vacum e de muito gado.

Não podia ir de S. Paulo: em março de 1700 o capitão-mor Pedro Taques de Almeida confessava a d. João de Lencastro, governador geral:

destas vilas não é possível fazer-se [a remessa das boiadas], porque sendo vinte já perecem os povos, nem se vende peso de carne, e valendo uma rês dois mil réis prometem os mineiros oito, pelo que interessam nas minas, porque o preço geral até o presente foi cinquenta oitavas e em alguma necessidade cem.

$\mathrm{O}$ recurso só podia partir da bacia do rio $\mathrm{S}$. Francisco.

Pelo dito rio ou pelo seu caminho, expõe um documento pouco posterior a 1705 , lhe entram os gados de que se sustenta o grande povo que está nas minas, de tal sorte que de nem uma outra parte lhe vão nem lhe podem ir os ditos gados, porque não os há nos sertões de São Paulo nem nos do Rio de Janeiro. Da mesma sorte se provêm pelo dito caminho de cavalos para suas viagens, de sal feito de terra no rio S. Francisco, de farinhas e outras cousas, todas precisas para o trato e sustento da vida. 
$\mathrm{O}$ rio $\mathrm{S}$. Francisco, acrescenta, desde a sua barra que faz no mar junto à vila de Penedo, em igual distância de oitenta léguas da Bahia e Pernambuco, de uma e outra parte, assim do que pertence à jurisdição de Pernambuco como à da Bahia (para os quais serve de divisão o dito rio) tem às suas beiras várias povoações, umas mais chegadas, outras mais distantes do dito rio; e na mesma forma se vão continuando por ele acima, por espaço de mais de seiscentas léguas, até se ajuntarem na barra que nele faz o rio das Velhas, em cuja altura se acham hoje as últimas fazendas de gados de uma e outra banda do dito rio de $\mathrm{S}$. Francisco, sem ter da dita barra até esta altura parte despovoada nem deserta em a qual seja necessário dormir ou alvergarem no campo os viandantes, querendo recolher-se na casa dos vaqueiros, como ordinàriamente fazem, pelo bom acolhimento que nelas acham.

Assim, como o alto Paraíba do Sul, mas em proporções muito mais grandiosas, também o rio de S. Francisco serviu de condensador da população.

À vista disto poder-se-ia esperar muitas vilas nestas regiões tão povoadas. Puro engano: só foram criadas no século XVIII, mais uma prova da diferença entre as capitanias del-rei e as de donatários na apreciação das municipalidades.

As câmaras do sertão não divergiam das do litoral, isto é, possuíam direito de petição, podiam taxar os gêneros de produção local, davam os juízes ordinários, mas eram antes de tudo corporações meramente administrativas.

Dos assentos da câmara do Icó no Ceará, instalada em 1738, constam posturas relativas ao plantio de mandioca para farinha e de carrapateira para o fabrico de azeite, à proibição de exportar farinha por causa da carestia, aos salários que deviam cobrar alfaiates, sapateiros e outros oficiais, à morte de periquitos, etc.

Nada confirma a onipotência das câmaras municipais descoberta por João Francisco Lisboa, e repetida à porfia por quem não se deu ao trabalho de recorrer às fontes.

$$
* * *
$$

À preocupação de minas cederam já Cristóvão Jaques e Martim Afonso. Nas suas capitanias esperavam encontrá-las João de Barros e sócios. Duarte Coelho contava descobri-las no rio de S. Francisco, e só deixou de ir pesquisá-las pessoalmente por circunstâncias alheias à sua vontade. Em Porto Seguro correram notícias de ouro uns quarenta anos depois da viagem de Pedr'Álvares. Luís de Melo da Silva embarcou-se à sua procura para as terras do Amazonas.

Tomé de Sousa dispôs uma expedição que transpôs a serra do Espinhaço. Sob seus sucessores volveram outros com pedras preciosas, especialmente esmeraldas. Pareceram por fim tais e tantos os vestígios de haveres a uma inteligência perspícua como a de Gabriel Soares, que abandonou o próspero engenho de Jeriquiriçá e perdeu anos com requerimentos junto às cortes de Lisboa e de Madrid para prestar à pátria o serviço de revelar-lhe as riquezas ocultas.

Dos metais de que o mundo faz mais conta, que é ouro e prata, escreve no último capítulo de seu monumental Tratado, - fazemos aqui tão pouca que os guardamos para o remate e fim desta história, havendo-se de dizer deles primeiro, pois esta terra da Bahia tem dele tanto quanto se pode imaginar; do que pode vir a Espanha cada ano maiores carregações do que nunca vieram das Índias Ocidentais, se Sua Majestade for disso servido.

A tentativa em que se meteu não provou a verdade destes assertos, mas perpetuou-lhe o nome. A ele prende-se a tradição de grandes viagens ao interior e de inexauríveis minas de prata. Melchior Dias, seu parente, ofereceu mostrar o metal branco em quantidade igual à do ferro em Biscaia. Após muitas negaças, intimado a cumprir a promessa, levou o governador geral do Brasil com alguns mineiros às serras de Itabaiana. As experiências feitas com azougue deram nada, com fogo deram fumo, informa testemunha de vista. Apesar de tudo continuou inabalável a crença nos tesouros ocultos de Melchior e na riqueza argentífera. Ainda no último quartel do século XVII procurava-se, esperava-se prata.

Partilhando das crenças de Gabriel Soares, d. Francisco de Sousa mandou do Espírito Santo às esmeraldas e de S. Vicente a Sabarabuçu. Quando veio-lhe substituto dirigiu-se para Madrid, onde conseguiu a separação do Estado em dois governos, em 1608; coube-lhe o do Sul com a superintendência exclusiva das minas em toda a colônia. Nestes trabalhos 
perdeu a vida em São Paulo; a esperança conservou sempre e soube comunicá-la a outros.

A incumbência dada a d. Francisco passou por sua morte a Salvador Correia e a alguns de seus descendentes, que durante quatro gerações pesquisaram ouro, prata, esmeraldas nos pontos mais diversos. Salvador neto adquiriu por fim certo cepticismo a propósito de metais; antes de qualquer outro convenceu-se da não existência de prata: "em sua consciência o declara que de Itabaiana para o Sul, quarenta léguas do mar, não há minas de prata, porquanto nestas partes andou ele conselheiro e fez todas as experiências para a descobrir, e é diferente terreno do de Potosi”, concluía no Conselho Ultramarino em 3 de maio de 1677. De Potosi podia falar com pertinência, pois fora até os Andes.

Por que se generalizou e persistiu esta crença com tanta pertinácia? Porque se acreditava na identidade estrutural do Ocidente e do Oriente da América; porque tomaram a malacacheta por prata, como Salvador afirma de Melchior Dias; porque nas ideias do tempo o Oriente era mais nobre que o Ocidente, e não podia faltar aqui o que abundava lá: "por boa razão de filosofia esta região deve ter mais e melhores minas que a do Peru", lê-se em documento escrito cerca de 1610, "por ficar mais oriental que ela e mais disposta para a criação de metais". Talvez influíssem também o nome do rio da Prata legado pelos primeiros navegadores e os informes confusos dos indígenas.

$\mathrm{O}$ ouro, não procurado ou procurado com menor afinco, aparecia entretanto às pequenas quantidades na capitania de S. Vicente. Desde o tempo de Mem de Sá encontraram alguns grãos Brás Cubas, provedor da fazenda, e Luís Martins, mineiro ido de Portugal.

Foram igualmente felizes outros. A crer na tradição houve descobertos riquíssimos; Afonso Sardinha, dizia-se, deixara oitenta mil cruzados de ouro em pó. Há de entrar exagero nesta conta, ou pelo menos muito ogó haveria no monte. Se tanto abundasse o metal, a população teria afluído aos bandos e os paulistas não levariam tanto tempo vida de bandeirantes.

Antonil-Andreoni parece mais próximo da verdade, quando diz a respeito destas primitivas lavras "que de um outeiro alto distante três léguas da vila de S. Paulo, a que chamam Jaraguá, se tirou quantidade de ouro que passava de oitavas a libras. Em Parnaíba, também junto da mesma vila no serro Ibituruna, se achou ouro e tirou-se por oitavas. Muito mais e por muitos anos se continuou a tirar em Parnaguá e Curitiba, primeiro por oitavas, depois por libras, que chegaram a alguma arroba posto que com muito trabalho para o ajuntar, sendo o rendimento no catar limitado".

Mais que as libras e oitavas, importam porém o gosto pelas pesquisas auríferas assim mantido e a prática do ouro de lavagem. Esta familiaridade influiu de maneira benéfica sobre o desenvolvimento ulterior da mineração.

D. Pedro II, depois de ver frustradas ou mal correspondidas todas as esperanças concentradas nas minas, resolveu dar um grande passo: dirigiu as mais lisonjeiras cartas à gente principal de São Paulo, confiando-lhe por assim dizer a questão.

Este apelo aos brios paulistas provocou o maior entusiasmo: um rei ainda se reputava então semideus, e uma carta régia honra quase sobrehumana. De chofre aparelharam-se e partiram nos rumos mais opostos numerosas bandeiras, e desde logo se evidenciou que, se o Brasil contivesse haveres minerais, não poderia conservá-los encobertos por mais tempo.

O mais famoso destes bandeirantes, transformado agora em mineiro pelo pedido do rei, chamava-se Fernão Dias Pais. Administrava algumas aldeias de índios Guanãan, desfrutava a casa grande característica da economia naturista e transmontara já o pino da vida. Alistou-se na cruzada do metal, apesar de tudo isto. Dez anos consumiu na porfia, e ao falecer nas matas do rio Doce levou a certeza de haver descoberto as célebres esmeraldas, secularmente esquivas.

Sua morte precedeu de pouco o despontar dos descobertos fenomenais. Garcia Rodrigues Pais era seu filho, uma filha sua esposara Manuel da Borba Gato, ambos astros de primeira grandeza nestes cometimentos.

De Minas Gerais o nome indica a fartura, a onipresença dos haveres. Quem os descobriu primitivamente é impossível apurar, tanto se contradizem as versões; o fato ocorreu pouco depois de 1690. Segundo Antonil-Andreoni, um mulato de Curitiba encontrou no riacho chamado Tripuí uns granitos cor de aço, que vendeu em Taubaté a Miguel de Sousa por meia pataca a oitava; levados ao Rio reconheceu-se neles ouro finíssimo. Foi este o primeiro descoberto. 
Seguiram-se o de Antônio Dias, a meia légua de Ouro Preto, o de João de Faria, o de Bueno e de Bento Rodrigues pouco mais distantes, os do ribeirão do Carmo e do Ibupiranga, todos nas cercanias de Ouro Preto e Mariana; parte da bacia do alto rio Doce foi escavada, justificando o nome de minas gerais primeiramente aplicado a este distrito.

Outros centros foram o rio das Mortes nas proximidades de São João e São José de El-Rei, caminho de São Paulo; o rio das Velhas, revelado por Manuel da Borba Gato, caminho da Bahia; Caeté e, ainda e sempre no alto rio Doce e na cordilheira do Espinhaço, o serro do Frio. Novas minas foram descobertas em Pitangui, Paracatu e alhures; já pertencem à segunda corrente e dispensam enumeração especial.

Dos caminhos primitivos um partia de S. Paulo, acompanhava o Paraíba, transpunha a Mantiqueira, cortava as águas do rio Grande e além bifurcava para o rio das Velhas ou o Doce, conforme o destino; outro ou saía de Cachoeira na Bahia e subia o rio Paraguaçu, ou tomando outras direções, passava a divisória do São Francisco, margeava-o a maior ou menor distância até o rio das Velhas que perlongava; o caminho do Rio seguia por terra ou por mar até Parati, pela antiga picada dos Guaianá galgava a serra do Facão nas cercanias da atual cidade do Cunha e em Taubaté entroncava na estrada geral de São Paulo. Mais tarde o entroncamento fez-se em Pindamonhangaba.

Artur de Sá, primeira autoridade que visitou os descobertos, tratou com Garcia Rodrigues Pais a abertura de uma linha mais direta de comunicações com a cidade de São Sebastião, a verdadeira capital do Sul. O filho de Fernão Dias deu conta cabal da incumbência. Nas proximidades da hodierna Barbacena reuniam-se os caminhos do rio das Mortes, o do rio das Velhas, e o do rio Doce; começou daí, venceu a Mantiqueira, procurou o Paraibuna, seguiu-o até sua barra no Paraíba e pela serra dos Órgãos chegou à baía do Rio, passando em Cabaru, Marcos da Costa, Couto e Pilar. O trecho entre o Paraíba e a baía já estava ligado em 1725 por outro caminho, devido a Bernardo Soares de Proença, correspondendo em parte ao traçado de E. de F. de Petrópolis a Entre-Rios, em parte acompanhando o rio Inhomirim.

Ainda uma década depois dos primeiros descobertos, custava um boi cem oitavas, a mão de sessenta espigas de milho trinta oitavas, um alqueire de farinha de mandioca quarenta oitavas, uma galinha três ou quatro oitavas, um barrilote de aguardente, carga de um escravo, cem oitavas, um barrilote de vinho, carga de um escravo, duzentas oitavas, um barrilote de azeite duas libras (libra $=128$ oitavas).

Não se pode crer o que padeceram ao princípio os mineiros por falta de mantimentos, achando-se não poucos mortos com uma espiga de milho na mão sem terem outro sustento, informa Antonil-Andreoni. "Porém tanto que se viu a abundância do ouro que se tirava e a largueza com que se pagava tudo o que lá ia, logo se fizeram estalagens e logo começaram os mercadores a mandar às minas o melhor que chega nos navios do Reino e de outras partes, assim de mantimentos como de regalo e de pomposo para se vestirem, além de mil bugiarias de França, que lá também foram dar... E não havendo nas minas outra moeda mais que ouro em pó, o menos que se pedia e dava por qualquer coisa eram oitavas.

Com vender coisas comestíveis, aguardente e garapas muitos em breve tempo acumularam quantidade considerável de ouro, - continua o mesmo autor. Porque como os negros e os índios escondem bastantes oitavas quando catam nos ribeiros e nos dias santos e nas últimas horas do dia tiram ouro para si, a maior parte deste ouro se gasta em comer e beber, e insensìvelmente dá aos vendedores grande lucro, como costuma dar a chuva miúda aos campos, a qual continuando a regá-los sem estrondo, os faz muito férteis. E por isso até os homens de maior cabedal não deixaram de se aproveitar por este caminho dessa mina à flor da terra, tendo negras cozinheiras, mulatas doceiras e crioulos taverneiros ocupados nesta redosíssima lavra, e mandando vir dos portos de mar tudo o que a gula costuma apetecer e buscar.

Sem serem procuradas apareceram as minas de Cuiabá. Pascoal Moreira Cabral e seus companheiros andavam à cata de índios quando encontraram os primeiros grãos de ouro em 1719, em tamanha abundância que extraía-se com as mãos e paus pontudos; tirava-se ouro da terra como nata de leite, na expressão pitoresca de Eschwege. Os bandeirantes viraram mineiros sem pensar e sem querer. A experiência das desordens das minas gerais foi aproveitada, e não houve aqui as terríveis desordens que fizeram tristemente célebre o rio das Mortes.

As notícias desta facilidade única de minerar, levadas ao povoado, agitaram a população, e levianamente se lançou à terrível jornada que começava no Tietê próximo do Itu, prosseguia pelo Paraná até junto das 
Sete Quedas, varava para as águas do Mbotetéu até sua barra no Paraguai e subindo por este procurava o São Lourenço e o Cuiabá. Muitos naufragaram; morreram outros de inanição ou devorados pelas feras; dos escapos à morte muitos perderam nos saltos e corredeiras as fazendas com que pretendiam negociar; as fazendas salvas chegavam podres a seu destino, porque não toldavam as canoas. $\mathrm{E}$ depois de tantos perigos encontravam a mais negra miséria em Cuiabá.

Alguns fatos narrados por Barbosa de Sá, testemunha e cronista desse período, mostram o horror da situação.

Só em 1721 chegou a primeira ferramenta para a mineração. Não havia pescadores e um dourado colhido acaso vendia-se por sete e oito oitavas. Muitos andavam opilados e hidrópicos, todos em geral com pernas e barrigas inchadas, com cores de defuntos; apetecia-se comer terra e muitos o faziam. Em 1723 apareceram os primeiros porcos e galinhas. Em 1725 chegou-se a dar por um frasco de sal meia libra de ouro $(256 \$$, a câmbio de 27). O milho, antes de brotado, era comido pelos ratos; depois de nascido caíam-lhe em cima os gafanhotos; se espigava, o sabugo saía sem grãos; o que granava tinha de ser colhido verde para os pássaros o não comerem. As ratazanas eram tantas que um casal de gatos foi vendido por uma libra de ouro, e os filhotes a vinte e trinta oitavas. Em 1729, por falta de fazendas, venderam-se camisas de alguns lençóis que se desfaziam a doze oitavas de ouro; a vara de algodão da terra a três e a quatro oitavas; sal não havia nem para batizado.

A situação melhorou muito lentamente. Em 1725 começou-se a navegação pelo Pardo, Coxim e Taquari, o que facilitava bastante a viagem, principalmente depois de se fazerem roças, criação de gado e até carros para transportar canoas no varadouro de Camapuã, entre o Paraguai e o Paraná.

Em 1728 plantou-se cana:

logo começaram a moer nas moendinhas que chamamos escaroçador e a estilar em lambiques que formavam de tachos, apareceram logo águas ardentes de cana que vendiam a cinco e seis oitavas de ouro e as frasqueiras a quarenta oitavas. Com isto foi que se começou a lograr saúde, a cessarem enfermidades e terem os homens boas cores que até então tinham-nas de defuntos, foram a menos as hidropisias e inflamações de barrigas e pernas e a mortandade de escravos que té aí se experimentava enterrando-se cada dia aos montões.
Até então a gente se concentrava nas cercanias de Cuiabá. Em 1734 transpuseram a serra e na região dos Parecis afloraram novas minas. Grandes florestas encontradas ali são a origem do nome de Mato Grosso. Em 1736 descobriu-se caminho por terra de Cuiabá ao Paraguai, e pelas águas do Guaporé a mineração foi se estendendo. Aquele ponto mais remoto ainda do que Cuiabá sofreu iguais misérias; despertou, porém, risonhas esperanças conhecer-se a existência de aldeias de jesuítas espanhóis a distâncias relativamente pequenas. Os primeiros que foram às reduções encontraram bom acolhimento e obtiveram algum gado. Brotou a ideia entabular comércio e logo outros aventureiros realizaram mais de uma expedição sem o fruto apetecido, porque ordens restritas vedaram quaisquer transações com os portugueses. Nas reduções encontraram notícia de estarem na bacia do Madeira.

Poucos anos antes Francisco de Melo Palheta chegara às aldeias do Mamoré, partindo do Pará. Animado por este exemplo, Manuel Félix de Lima em 1742 atirou-se ao rio Guaporé e foi sair em Belém. Mais tarde João de Sousa de Azevedo embarcou no Arinos, foi dar no Tapajós e voltou pelo Madeira. Apesar das dificuldades de navegação ainda hoje não vencidas, a viagem de um e outro rio foi repetida e aqueles sertões de Noroeste ficaram ligados à baixada do Amazonas.

Outra ligação se estabelecera antes com S. Paulo por via terrestre para evitar os índios brabos. Desde a barra do São Lourenço começaram os Paiaguás e Guaicurus a perseguir as pessoas que iam para Cuiabá ou de lá tornavam. Apareciam de súbito em inúmeras canoas, e conhecendo os mínimos acidentes dos pantanais escolhiam os pontos de ataque e sabiam furtar-se aos que perseguiam. Diz-se que obravam incitados pelos castelhanos de Asunción e é muito possível, porque mineiros e bandeirantes não eram vizinhos para se desejar. Em todo o caso o ouro que tomavam encontrava a saída no Paraguai e tanto bastava para estimulá-los em seus salteios.

O primeiro destes sucessos ocorreu em 1725. Diogo de Sousa com muita gente entrava no Xané, no delta do S. Lourenço, quando apareceu o gentio. Foram mortas seiscentas pessoas: salvaram-se apenas um branco e um preto: como troféu e despojo, os Paiaguás levaram vinte canoas. Repetiram-se os ataques nos anos seguintes, ora mais perto, ora mais longe do Taquari, ponto obrigado depois das plantações do Camapuã e da 
navegação do Pardo. No meio de expedições para tomar vingança dos Bárbaros, surgiu a ideia de abrir caminho para Goiás e o povo concorreu com três mil oitavas para a obra. Realizou-se Antônio Pinto de Azevedo, que já estava de volta a Cuiabá em setembro de 1737, com cavalarias e gados, os primeiros ali introduzidos.

Os descobertos de Cuiabá lembraram a Bartolomeu Bueno da Silva que, uns quarenta anos antes, percorrendo os sertões em companhia de seu pai, o primeiro Anhanguera, vira entre os índios Guaiá pepitas de ouro servindo-lhes de ornatos. Deviam ser muito auríferas aquelas regiões, pois o metal chegara a atrair a atenção do aborígene. Sentiu-se capaz de achá-las outra vez, ofereceu-se a tentá-lo e seu oferecimento aceito, partiu de São Paulo em janeiro de 1722.

Fiara demais de sua retentiva: durante mais de três anos andou a esmo em todos os sentidos, até as cabeceiras do Araguaia; parte de sua gente desceu o Tocantins e chegou ao Pará; parte caiu em encontro com os índios, parte morreu de fome; depois de comidos os cachorros e alguns cavalos,

fiz trinta e cinco sermões sem mudar de tema", conta um companheiro do segundo Anhanguera, "animando a todos que não esmorecessem, certificando-lhes para diante rios de muitos peixes, campos de muitos veados, matos de muita caça, mel e guarirobas. Perguntavam os miseráveis: quando? Respondia-lhes: nestes dias, e nestes permitia Deus que chegássemos e tudo se achava certo. Com isto cessaram as mortes e não morreu mais ninguém, e mal de muitos se não fora o pregador.

Afinal, em 21 de outubro de 1725, Bartolomeu Bueno chegou triunfante a S. Paulo, assegurando iguais grandezas às de Cuiabá, com a vantagem dos ares não serem tão contagiosos. Os rios, cujas passagens lhe foram concedidas e a seu sócio Bartolomeu Pais de Abreu, pai do benemérito historiador paulista Pedro Taques, dão ideia aproximada do seu itinerário, a trechos seguido no traçado da E. F. Mogiana: Atibaia, Jaguari, Mogi, Sapucaí, Pardo Grande, Velhas, Paranaíba, Corumbá, Meia-Ponte e Pasmados.

A primeira mineração condensou-se no rio Vermelho, afluente do Araguaia; mas também aqui apareceram minas generalizadas e os mineiros se dispersaram.
Em 1733 Domingos Rodrigues do Prado descobriu as de Crixás, Manuel Dias da Silva as de Santa Cruz e Calhamare as de Antas; no mesmo ano Manuel Rodrigues Tomar descobriu as de Água-Quente e nos seguintes as de S. José e Traíras; em 1734 Carlos Marinho descobriu as de S. Félix, em 1736 descobriu as de Cachoeira, Santa Rita e Moquém; em 1737 Francisco de Albuquerque Cavalcante descobriu as que guardam seu nome; datam de 1739 o descoberto de Amaro Leite, de 1740 o de Arraias, devido a Francisco Lopes, de 1740 o de Pilar, devido a João de Godói Pinto da Silveira, de 1746 o de Santa Luzia, devido a Antônio Bueno de Azeredo. Estas datas são aproximadas, e variam com os cronistas.

A situação geográfica de Goiás permitia-lhe fàcilmente comunicar-se com a baixada amazônica e com os chapadões de Parnaíba, de S. Francisco e do Paraná; sua aparição tardia na história e relativa proximidade caminho de São Paulo pouco tempo conservou-se único; apesar das proibições repetidas e arbitrárias abriram-se mais outras picadas, e gados e aventureiros afluiram de Minas Gerais, Bahia, Pernambuco, Piauí e Maranhão. Já se viu que poucos anos depois daqui partiram recursos para os cuiabanos.

Várias expedições se organizaram à procura de jazidas particularmente abundantes, sibilinamente anunciadas em roteiros misteriosos: Martírios, assim chamados da semelhança entre as formas das rochas vizinhas e os instrumentos da Paixão, Araez, rio Rico, etc. Nos roteiros, observa Eschwege, que ainda alcançou alguns, guardados ciosamente nas famílias, três irmãos ou três irmãs podem ser três serras ou três rios; juntamente com a trindade, anda em geral a alavanca encostada à gameleira, ou a corrente pregada ao cedro, ou o prato de estanho largado numa loca, designados como conhecenças inequívocas do tesouro e nunca vistos. Os Martírios, se de fato existem, aguardam ainda descobridor.

A estas três capitanias auríferas cumpre agregar a da Bahia, não menos rica. Jacobinas e rio de Contas, este sobretudo, justificaram todas as esperanças do velho Gabriel Soares; mas a metrópole julgou estes descobertos demasiado próximos do litoral, expostos portanto a assaltos de piratas, e proibiu fossem minerados. O veto respeitou-se o menos possível, embora se guardassem as aparências; daí certo ar de clandestinidade de especificá-la. Mais tarde a proibição foi levantada; contudo Bahia 
continuou antes agrícola e pastoril que mineira, e Goiás afogou-a com o seu esplendor.

As Ordenações do Reino enumeravam as minas entre os direitos reais. Como a experiência de quase um século patenteasse a dificuldade de desfrutá-las, triunfou a ideia, sugerida talvez por d. Francisco de Sousa e incorporada no regimento de 1603 , de permitir a lavrança, com a ressalva do quinto para a Coroa. Enquanto o ouro andou por oitavas e libras, a porcentagem foi por assim dizer deixada aos escrúpulos de cada mineiro, mera afirmação de um princípio teórico; com os descobertos gerais de Cataguases transformou-se em propulsor de todo o mecanismo colonial.

No caos inicial a única autoridade, o guarda-mor, demarcava os lotes e apartava para o rei uma data, adjudicada em licitação a quem mais desse. O quinto cobravam provedores ad hoc ou arrecadavam registos colocados em pontos de passagem forçada: Taubaté, para quem procurava São Paulo, ou Parati, no caminho do Rio. Nas ribeiras do São Francisco a coleta ficava mais difícil, porque a partir do arraial de Matias Cardoso, perto da atual Januária, abriram-se muitos caminhos para o Norte e nascente; pelo rio desciam canoas e muitos preferiam este veículo, mais seguro e mais econômico. A dificuldade de arrecadação ainda avultou quando Garcia Pais estabeleceu comunicação direta com a baía do Rio de Janeiro. Mesmo assim o rendimento foi considerável.

Nova era começa em 1711, com a chegada de Antônio de Albuquerque, a criação de vilas e a instalação das municipalidades. Albuquerque reuniu as câmaras e pessoas mais notáveis, para assentarem o melhor meio de garantir os interesses da Coroa. Parecia racional uma capitação paga por cada bateia empregada na lavra; as câmaras preferiram impostos de entrada sobre fazendas secas, molhados e escravos. A invasão de Duguay-Trouin chamou o governador ao Rio; o ponto ficou suspenso; continuaram os registros e o sistema antigo.

Brás Baltásar da Silveira, novo governador, aceitou o oferecimento feito pelas câmaras de Vila-Rica, Sabará e Carmo, de darem anualmente, em paga do quinto, trinta arrobas de ouro $(1$ arroba $=16: 834 \$ 000$, ao câmbio de 27); para auxílio da cobrança, concedeu-lhes d. Brás uma quota no direito das entradas. Durou esta avença um quinquênio, sem que o governo da metrópole jamais parecesse satisfeito.
De 1718 a 1722, as câmaras abriram mão da quota de importação e obrigaram-se a pagar anualmente vinte e cinco arrobas. A corte encheu-se, porém, de escrúpulos com a injustiça da capitação até ali vigente; preferiu casas de fundição, a que seria recolhido todo o ouro em pó, reduzido a barras e desde logo quintado. Avessas a este sistema, as municipalidades propuseram pagar trinta e sete arrobas e assim se fez até 1725.

De então até 1750 vigorou, ora o sistema de capitação, ora o de casas de fundição. Estas foram definitivamente estabelecidas desde o começo do reinado de José I; afiançaram as câmaras o rendimento anual de cem arrobas; havendo sobra, poderia servir para cobrir de déficit do ano seguinte; se este apresentasse também sobra, a do ano anterior ficava pertencendo definitivamente à Coroa; se houvesse déficit e não pudesse ser suprido pelo modo indicado, proceder-se-ia à derrama, isto é, cada municipalidade concorreria proporcionalmente, de modo a completar-se a centena de arrobas. A câmara mais opulenta, a de Vila-Rica, tinha, como recursos exclusivos, os aferimentos de pesos e medidas, os foros das casas, a renda dos açougues e a da cadeia; somado tudo não chegava a cinco contos ânuos. Quer isto dizer que a escrupulosa metrópole passava adiante a responsabilidade na odiada capitação.

Levariam longe os pormenores do regime fiscal, imposto a Minas Gerais e, até onde o permitiam as distâncias e a população esparsa, à Bahia, Goiás e Mato Grosso; a proibição de abrir novas picadas, a proibição de fundar novos engenhos, a proibição de andar com ouro em pó, a proibição de andar com ouro amoedado, a proibição de exercer o ofício de ourives, os impostos múltiplos, os donativos implorados por prazo certo e curto e depois exigidos imperiosamente por prazo muito maior, estranhando-se a ousadia de suspendê-los nos termos do acordo inicial, mostrariam até onde pode chegar uma administração sem melindres e sem inteligência e uma gente sem energia, se não fosse o distrito adiamantino.

Apenas uma amostra. Divulgada em 1730 a existência de diamantes no Tijuco, logo d. Lourenço de Almeida, governador de Minas Gerais, estabeleceu a capitação de $5 \$$ por cada escravo empregado nas lavras; no ano seguinte mandou despejar as minas, expulsar da comarca do Serro negros, mulatas e mulatos forros, limitar a mineração a certa zona, pagando-se pelo menos $60 \$$ anualmente, afinal por muito favor reduzidos a $20 \$$, proibiu vendas fora do povoado e só as permitiu na povoação com o 
sol de fora; em 1734 a capitação foi elevada a 40\$, e logo em seguida vedada a mineração e mandado que nem um dos habitantes do distrito pudesse ter bateia, almocrafe, alavanca ou qualquer outro instrumento de minerar. Com o tempo foi-se tornando mais tirânico o regime, de modo a permitir que a Coroa portuguesa ficasse senhora do mercado de diamantes do mundo inteiro.

O ouro produzido no Brasil escapa a qualquer avaliação exata. Levando em conta uma porção de dados, Calógeras calcula que Goiás e Mato Grosso, desde o começo da mineração até 1770, deram uma produção total de nove mil arrobas; daquela data a 1822 mais umas duas mil e quinhentas: ao todo cento e noventa mil quilogramas. Entre São Paulo, Bahia e Ceará haveria mais setenta e cinco a oitenta mil. Chega-se assim ao total de duzentos e setenta mil quilos para a produção destas partes do Brasil, durante o período colonial até 1822.

Para Minas Gerais avalia-se em sete mil e quinhentas arrobas do princípio até 1725; em seis mil e quinhentas arrobas a produção dos onze anos seguintes; em doze mil arrobas de 1736 a 1751; em dezoito mil arrobas de 1752 a 1787; em três mil e quinhentas a quatro mil arrobas de 1788 a 1801; em três mil e quinhentas arrobas de 1801 a 1820 . Até 1820 a extração total em Minas devia andar por 51.500 arrobas, digamos 772.500 quilogramas.

Os quintos representam apenas uma parte do regime fiscal: havia mais os dízimos, os direitos das entradas, as passagens dos rios.

Os dízimos, estabelecidos em 1704, rendiam no tempo de Teixeira Coelho mais de sessenta contos anuais: para os seis anos e cinco meses decorrentes do primeiro de agosto de 1777 ao último de dezembro de 1783 o contrato foi arrematado por 388 contos.

Os direitos de entrada cobravam-se nos registros do caminho novo, da Mantiqueira, do Itajubá, do Jaguara, do Ouro-fino, do Jacuí, de Sete Lagoas, do Jequitibá, do Zabelê, do ribeirão da Areia, de Nazaré, de Olhos d'Água, de S. Luís, de Santo Antônio, de Santa Isabel, do Pé do morro, do Rebelo, do Inhacica, do Caeté-mirim, do Galheiro, do Bom-Jardim, de Simão Vieira, de Jequitinhonha, de Itacambira, do rio Pardo. Pagavam entrada os escravos introduzidos pela primeira vez, cabeças de gado vacum, muar ou cavalar, e as cargas de fazenda seca ou molhada. Por molhados entendiam-se os comestíveis, ferro, aço, pólvora e tudo o mais impróprio para se vestir. O rendimento das entradas em 1776 foi de mais de cento e quarenta e sete contos.

Pagava-se passagem nos rios Sapucaí, Verde, Mortes, Grande, Paraupeba, Velhas, Urucuia, Baependi, Pará, São Francisco, Jequitinhonha. Ofícios de justiça e fazenda pagavam também donativos, terças e novos direitos.

$\mathrm{Na}$ constância da derrama surgiram os primeiros fenômenos da decadência da mineração. Explicaram-na pelos extravios cada vez mais numerosos, graças à multiplicidade de vias de comunicação. Teixeira Coelho, que passou onze anos em Minas, ocupando altos empregos, e deixou escrito precioso sobre a capitania, indica outras causas: a pobreza dos mineiros; falta de negros, monopólios deles e direitos excessivos que pagavam; abusos nas concessões dos guardas-mores; demandas sobre terras e águas minerais; mau método de minerar; demandas sobre os privilégios dos mineiros a que chamam da trintada, divisão das fábricas por heranças, etc.

Todos estes males influem sensivelmente na decadência das minas, observa Eschwege, mas todos eles procedem de duas únicas causas, e são terem se franqueado ao povo as minas sem limitação e sem inspeção sobre seus trabalhos e a falta de leis montanísticas adequadas a este país... Os mineiros do país aproveitam só o que podem separar mecânicamente e de uma maneira muito imperfeita. Assim, contando todas as perdas que sofrem, causadas pela sua ignorância, desde que tiram o ouro do seu leito natural até que sai fundido da casa de fundição e da moeda, não será por certo exagerado quem avaliar estas perdas em a metade do mesmo ouro...

Desenganada de ouro, a população procurou outros meios de subsistência: a criação do gado, a agricultura de cereais, a plantação de cana, de fumo, de algodão; com o tempo avultou a produção ao ponto de criar-se uma indústria especial de transportes, confiada aos históricos e honrados tropeiros.

Diversas tentativas se fizeram para atravessar a mata e comunicar diretamente com o mar. A mais feliz consistiu na passagem do alto rio Doce para o Pomba, iniciada por 1766. A presença de poaia facilitou o comércio com os índios daquelas regiões. Coroados, Coropotos, extratores da erva 
medicinal, cujo emprego, segundo uma tradição encontrada por Martius, lhes ensinou a irara: "asseguraram-nos", escreve ele, "que estes filhos da natureza aprenderam o uso da raiz hemética com a irara, espécie de marta, que costuma, quando bebeu demais água impura ou salgada de muitos riachos e tanques, mastigar a raiz e a erva para provocar vômito. Contudo isto pode muito bem ser uma das muitas histórias infundadas que sem exame os portugueses receberam dos índios".

Assim, a penetração ou melhor a exteriorização fez-se rápida através da zona de ipecacuanha. Já na era de 780 Miguel Henrique, o Mão de Luva, chegava por este caminho às minas de Cantagalo. Mais tarde plantou-se café naquela comarca, que desceu o Paraíba ou procurou o porto de Magé (por Aparecida, Serra do Capim, Paquequer, estrada construída pelo barão de Aiuruoca), enquanto não pode servir-se da Estrada de Ferro de Pedro II e da Estrada de Ferro da Leopoldina.

$$
* * *
$$

Os triunfos colhidos em guerras contra os estrangeiros, as proezas dos bandeirantes dentro e fora do país, a abundância de gados animando a imensidade dos sertões, as copiosas somas remetidas para o governo da metrópole, as numerosas fortunas, o acréscimo da população, influiram consideravelmente sobre a psicologia dos colonos. Os descobertos auríferos vieram completar a obra. Não queriam, não podiam mais se reputar inferiores aos nascidos no além-mar, os humildes e envergonhados mazombos do começo do século XVII. Por seus serviços, por suas riquezas, pelas magnificências da terra nata, contavam-se entre os maiores beneméritos da coroa portuguesa.

Tal transfiguração não se deram pressa em reconhecer os filhos do além-mar. Daí atritos frequentes. Gregório de Matos, baiano que se formara em Coimbra e aliás não revela simpatia particular pelos patrícios, já na segunda metade do século XVII manejava o látego da sátira contra o reinol: vem degradado por crimes ou fugido ao pai, ou por não ter o que comer, salta no cais descalço, despido, roto, trazendo por cabedal único piolhos e assobios, curte a vida de misérias, amiúda roubos, ajunta dinheiro, casa rico e ocupa os cargos da república! De outra parte não faltariam respostas mordazes e remoques equivalentes.
Destes atritos e malquerenças a primeira manifestação pública explodiu nas terras do ouro com a chamada guerra dos Emboabas, uma das designações dos reinóis na língua geral. Para o caso de que vamos agora tratar a designação era pouco rigorosa. Naquelas brenhas tão alongadas do litoral devia haver poucos portugueses; é provável, quase certo, estivessem em minoria nos combates: mas a alcunha, além de afrontosa, resolvia uma questão difícil: como chamar os adversários, em sua maioria gente da ribeira do São Francisco, se muitos vieram de São Paulo ou procediam de paulistas, e eram baianos os de uma, pernambucanos os de outra margem? Chamavam emboabas a todos os que não sairam de sua região, explica Rocha Pita.

Os paulistas afetavam profundo desprezo pelo emboaba, tratavam-no por vós, como se fora escravo, informa o cronista destes sucessos. Durante o prazo de sua prepotência entre a serra da Mantiqueira e a do Espinhaço, nas primeiras décadas da anarquia incompreensível, entregaram-se aos maiores excessos e só a força deu leis. Um dia, ante a violência praticada à sua vista contra um pobre diabo, protestou Manuel Nunes Viana, emboaba poderoso, afazendado nas margens do Carinhanha, prático em guerras contra o gentio do S. Francisco, nas quais conquistara o posto de mestre de campo. Tanto bastou para promoverem-no a chefe dos oprimidos. Os paulistas por sua vez sentiam-se espoliados com a presença de tantos forasteiros. Conservam ódio aos reinóis, lembrava Antônio Rodrigues da Costa, no Conselho Ultramarino de que era membro, porque os reputam por usurpadores daquelas riquíssimas minas, que eles entendiam firmemente serem patrimônio seu, que lhes havia dado ou a sua fortuna ou a sua indústria. Entre espoliados e oprimidos o conflito era fatal.

A morte da gente miúda não se levava em conta, mas um dia os forasteiros mataram José Pardo, paulista poderoso, e seus patrícios começaram a se armar, para em janeiro do seguinte ano de 1709 dar cabo dos emboabas. Estes, fogosos agora com o prestígio do chefe eleito, anteciparam a ameaça e sairam à procura do inimigo para dar-lhe combate. A força de São Paulo, que descuidosa acampava junto ao rio das Mortes, recolheu-se a um capão quando chegou a multidão arrebanhada no rio das Velhas e alto rio Doce. De cima das árvores os paulistas disparam tiros certeiros, mas sua resistência não podia aturar muito, por estar cercado o mato de modo a não permitir saída e além disso falecerem víveres. Espalhou-se que os emboabas se contentariam com desarmar os contrários, 
e estes, fiados na promessa vaga, pediram bom quartel, prometendo entregar as armas. Concedeu-lho Bento do Amaral Gurgel, cabo da força atacante, fluminense de instintos sanguinários; apenas, porém, os viu indefesos "fez um tal estrago naqueles miseráveis que, deixando o campo coberto de mortos e feridos, foi causa de que ainda hoje se conserve a memória de tanta tirania, impondo àquele lugar o infame título de capão da Traição".

Ensoberbecidos com esta vitória, os emboabas proclamaram Manuel Nunes Viana governador daquelas minas. $\mathrm{O}$ aclamado, alheio às malfeitorias e crueldades de Bento do Amaral, praticadas longe de suas vistas e sem seu assentimento, mostrou-se capaz do cargo; elevou-se de chefe de partido a cabeça de governo, criou juízes, distribuiu postos, ofícios e patentes, regularizou a concessão das minas, cobrou os quintos devidos ao régio erário, arrecadou direitos sobre os gados e fazendas importadas, sopeou a anarquia reinante. Excessos praticou necessariamente, nem com a facilidade poderia evitá-los, mas sua obra foi benéfica e depois dela percebe-se o arrefecimento da barbárie universal. Era aliás um espírito de certa cultura; gostava de ler a Cidade de Deus e obras congêneres; a suas expensas se imprimiu o Peregrino da América de Nuno Marques Pereira, um dos mais apreciados livros para nossos avós do século XVIII, como provam suas numerosas edições.

A notícia dos sucessos do rio das Mortes atraiu às minas Fernando de Lencastro, governador do Rio. Os espíritos estavam ainda muito excitados para reconhecer-lhe a autoridade, mesmo se admitissem sua imparcialidade e desta com razão ou sem ela duvidavam. Em Congonhas, próximo de Ouro Preto, Nunes Viana saiu-lhe ao encontro, rodeado de cavalaria e infantaria, e o governador intimidado fez-se de volta para sua capital. Diz-se que secretamente procurou-o o chefe dos emboabas, assegurando-lhe sua lealdade, prometendo sujeitar-se à ordem legal apenas serenasse a efervescência de sua gente. Parece exata a história, pois quando mais tarde acudiu Antônio de Albuquerque, sucessor de d. Fernando, acompanhado apenas de dois capitães, dois ajudantes e dez soldados, Nunes Viana entregou-lhe voluntàriamente $\mathrm{o}$ mando e recolheu-se a suas fazendas na margem pernambucana do São Francisco.

Donde menos se esperava anunciou-se nova procela. Os paulistas, sobreviventes ao morticínio do capão da Traição, foram recebidos em sua terra com desprezo até das próprias mulheres, que "blasonando de Pantasiléas, Semiramis e Zenobias, os injuriavam por se haverem ausentado das minas fugitivos, e sem tomarem vingança dos seus agravos, estimulando-os a voltar na satisfação deles com o estrago dos forasteiros". Estas palavras ardentes encontraram eco; Piratininga tornou-se praça de guerra; numerosos voluntários, sedentos de vingança, gruparam-se à roda de Amador Bueno da Veiga e se encaminharam para além da Mantiqueira. Sua marcha foi bastante vagarosa. Saiu-lhes ao encontro Antônio de Albuquerque, esperançado em ser tão bem sucedido com eles como fora com os emboabas. Enganou-se, porém; a marcha vagarosa dos paulistas não provinha de hesitações ou receios e por tal modo receberam o governador que dali mesmo seguiu para o Rio pelo velho caminho de Parati, receioso de ser preso por aqueles súditos turbulentos. Da cidade, pelo caminho novo de Garcia Pais, mandou avisar os emboabas do perigo que os ameaçava.

Assim tiveram tempo de se aparelhar e fortalecer até chegar Amador Bueno com seus mil e trezentos soldados. Feriu-se logo o combate e durou vários dias; alguns paulistas, desanimados com a resistência, falaram em levantar o cerco; alguns emboabas, à vista da mortandade nas próprias fileiras, pensaram em se render. O ódio era demasiado forte de parte a parte para prevalecer qualquer solução mais humana. Afinal, quando os emboabas já não podiam se manter e dispunham uma sortida desesperada, misteriosamente retiraram-se os paulistas, talvez com o boato de marcharem do rio das Velhas e de Ouro Preto forças consideráveis. Não deram com isso a partida por perdida e trataram de preparar ou fingiram preparar outra expedição mais forte para recomeçar a luta; interveio, porém, d. João V, com o prestígio semi-divino da realeza naquelas inteligências rudimentares: "entendendo o soberano que ânimos generosos se deixam vencer com qualquer afago, lhes enviou pelo novo governador um retrato seu... para que entendessem que visitando-os daquele modo, já que pessoalmente o não podia fazer, tomava aos paulistas debaixo de sua real proteção". Com este singular presente se satisfizeram, e esquecidos dos agravos passados depuseram as armas.

Depois da guerra dos emboabas, houve ainda desordens em Minas Gerais, uma delas, em 1720, sufocada enèrgicamente; não mais inspirou-as o espírito de nativismo, isto é, a queixa de espoliação e sua importância é meramente provinciana. 
Mal estavam pacificadas as terras do ouro e já rebentava a manifestação análoga na capitania de Pernambuco.

Depois da expulsão dos flamengos, o governador fixou residência em Olinda, e nela o primeira bispo estabeleceu a sede da diocese em 1688. A nobreza antiga reedificou a casaria destruída, que ocupava só por ocasião das festas, pois a maior parte do ano passava nos engenhos. O Recife, graças à superioridade do porto, continuou a prosperar e adquiriu população numerosa e permanente; preferiam-no para morada os negociantes, gente que em geral procurava enriquecer depressa, para ir desfrutar a fortuna no além-mar. Os olindenses olhavam para eles com toda a soberania, de sua prosápia e de seus postos, desdenhosamente chamavam-nos mascates, e andavam sempre em rusgas por causa de contas queixando-se uns de usura e extorsão, outros de mau pagamento e má fé.

Depois de enriquecer, alguns recifenses procuravam ter também parte no governo, obter hábitos e ganhar postos de milícia. Conseguiram-no com grande indignação da nobreza, acostumada ao privilégio destas honrarias. Em 1703 fizeram não só eleitores como um vereador. Com isto tanto mais se exacerbaram as paixões. Olinda aproveitou sua dupla superioridade de capital civil e eclesiástica para a todo propósito amesquinhar a rival. Desde então empenharam-se os mascates em obter para o Recife o título de vila, condição de autonomia dos negócios municipais. Enquanto reinou d. Pedro II, lembrado ainda da guerra dos vinte e quatro anos, valeu a oposição da nobreza; d. João V cedeu à influência contrária poucos anos depois de haver subido ao trono.

A solução ofendeu os brios olindenses, mas talvez não provocasse violências se a outro coubesse executar a ordem régia. Governava capitania Sebastião de Castro Caldas, ex-governador do Rio e da Paraíba, português leviano, sarcástico, desdenhoso dos subordinados, adito dos reinóis. A 15 de fevereiro de 1710 levantou o pelourinho da vila nova, em honra sua chamada de S. Sebastião; a 3 de março levantou outro com maior solenidade, por não ser bastante o primeiro. A delimitação do termo de Recife, a jurisdição dos juízes ordinários, a serventia dos diversos ofícios malquistaram o ouvidor, o juiz de fora e o juiz ordinário com o governador. Correu que se pretendia depô-lo, como em 1666 se fizera a Jerônimo de Mendonça Furtado. Sob este pretexto, verdadeiro ou falso, começou ele a prender pessoas importantes, e ameaçava ainda outras quando a 17 de outubro desfecharam-lhe um tiro às 4 horas da tarde, no meio da rua. Já tardava este desfecho: "em Pernambuco se acha que mais gente se tem morto a espingarda depois de sua restauração do que matara a mesma guerra", escrevera-se alguns anos antes.

Não foram pegados os três mandatários nem se descobriu mandante. Caldas, ligeiramente ferido, proibiu que a dez léguas do Recife andasse alguém armado e mandou prender mais gente. $\mathrm{O}$ fato de superintender a tudo sem se recolher ao leito deu azo aos agitadores para espalharem ser fingido o ferimento e o tiro mandado dar por ele próprio; a proibição de andar-se armado apontaram como prova de estar disposto a entregar a terra aos franceses, que acabavam de atacar o Rio. Com isto cresceu a fermentação; perdendo a calma, o governador expediu vários destacamentos às freguesias da mata, a efetuar novas prisões. Levantou-se o povo; parte da tropa foi cercada, parte capitulou, parte fraternizou, e levas numerosas de populares puseram-se em marcha para o Recife.

A 5 de novembro chegou à praça a notícia do levante; a 6, Caldas tentou negociar com os levantados, que a nada quiseram atender; a 7 de madrugada embarcou numa sumaca para a Bahia, levando consigo alguns dos mais odiados de seus partidários.

Dos populares, recrutados pela maior parte em Santo Antão, S. Lourenço, Jaboatão, Varge, Muribeca, alguns eram movidos sobretudo pela pretensa traição do governador; a outros instigava ódio aos mascates, e formava artigos de seu programa o saque do Recife. Tê-los dissuadido deste projeto deveu-se principalmente aos religiosos regulares e seculares. $\mathrm{Na}$ entrada da nova vila houve algumas violências, mas de pequeno vulto e a tempestade desfez-se sem os estragos temidos. O pelourinho foi derribado, anulada a eleição, inutilizados os pelouros, privados de insígnias os oficiais mascates; um ou outro devedor menos consciencioso liquidou as contas sumàriamente; contudo houve mais farsas e desfeitas que violências e desforços.

Com retirada de Sebastião de Castro vagara o lugar de governador; abertas as vias de sucessão para saber o nome do substituto, saiu o do bispo da diocese. Alguns insurgentes opuseram-se à posse. Bernardo Vieira de Melo, sargento-mor, um dos cabos na guerra dos Palmares, propôs se proclamasse umas república à moda de Veneza ou se procurasse a proteção de alguma potência cristã. Hoje é festa estadual em Pernambuco o dia 10 de 
novembro, em honra deste gesto peregrino. Que ideia formava da república e da adaptabilidade a terras tão atrasadas, a povo tão alheio às práticas políticas e administrativas, de organismo complexo e delicado qual a constituição veneziana, provàvelmente se ignorará até a consumação dos séculos. Ouvira, talvez, falar no seu caráter aristocrático e ingenuamente equiparava a nobreza de Olinda aos cultos patrícios das lagunas. Do protetorado de qualquer nação cristã que se poderia seguir? Esperava-o fim idêntico ao da invasão flamenga, — bem o provava o atual movimento, triunfante graças principalmente à crença que se divulgou da convivência do governador expulso com os franceses. De resto podem ser falsas estas alegações, transmitidas só por adversários rancorosos, empenhados em agravar as culpas dos vencidos. Acabou-se reconhecendo legítimo o sucessor indicado pelas vias de sucessão, Sua Ilustríssima o Senhor d. Manuel.

D. Manuel Álvares da Costa, chegado de Portugal no começo do ano, mantivera com o representante do poder civil as relações antes frias que cordiais de praxe entre os cabeças das duas sociedades perfeitas. Ao ser informado do tiro, foi visitar o ferido de quem na mesma ocasião se despediu por ter de partir para a Paraíba. Em caminho agregou-se à comitiva, como dias antes convencionara, José Inácio Arouche, o exouvidor malquistado com o governador a propósito da divisão do termo do Recife, e objeto de ódio muito particular seu e dos mascates, apesar de português. Sebastião de Castro implicou-o entre os mandantes do crime a fautores da conspiração, deu ordem de capturá-lo e, não sendo achado em casa, mandou segui-lo até onde fosse encontrado: era fácil a diligência, pois Arouche não andara com mistérios.

A 20 de outubro amanheceu cercada a igreja de Tapirema, onde pernoitara o bispo, por uma tropa de soldado encarregada de realizar a prisão. D. Manuel escreveu a Sebastião de Castro protestando contra a desatenção à sua pessoa e descomposição imerecida e obrigando-se a dar conta do perseguido. A resposta foi remessa de força mais numerosa, acusações odiosas contra o ex-ouvidor, ordem de trazê-lo vivo ou morto:

se o dito doutor está inocente, tenho bens com que satisfazer-lhe a injúria e cabeça com que pague quando por este respeito mereça castigo... Este doutor ficou em Pernambuco ou por pecado da terra ou pelo meus, pois não só embaraçou o meu governo, mas pôs a V. S. ${ }^{a}$ em ódio com as sua ovelhas, como é público e notório, pois todos reconhecem as letras e virtudes de $\mathrm{V}$. S. ${ }^{\mathrm{a}}$ e atribuem aos seus conselhos e vinganças tudo quanto se tem visto e experimentado.

Arouche escapou à prisão porque sacerdotes do lugar deram-lhe escapula e por caminhos desviados levaram-no à Paraíba.

D. Manuel voltou para Olinda no dia 10 de novembro, a 15 tomou posse do governo e logo, para aquietar os povos sublevados desde São Francisco até Paraíba, perdoou-lhes a revolução e o tiro, "confiado na grandeza de el-rei nosso senhor que Deus guarde, o haja de confirmar".

Seguem-se alguns meses de calma aparente. A nobreza desfrutava ruidosamente a vitória, dando tudo terminado; apenas em junho do ano seguinte falou-se de tirar proveito das fortalezas para impedir o desembarque do novo governador, se não trouxesse o perdão esperado, ou permiti-lo sòmente sob certas condições.

Entretanto a inércia dos mascates encobria um trabalho de mina muito ativo. Com habilidade foram separadas da causa de Olinda as freguesias situadas entre o cabo de Santo Agostinho e o rio S. Francisco, obtida a cooperação do capitão-mor da Paraíba, do mestre de campo dos Henriques, do governador dos índios, do comandante da fortaleza de Tamandaré; aos poucos, para não despertar atenção, reunidos víveres em quantidade suficiente para resistir a um cerco; aliciado o terço do Recife com seus oficiais, fiéis a Sebastião de Castro até a última hora. Esta pelo menos é a versão olindense. Como nada transpirou até o momento decisivo dificilmente se compreende; não se sabe o que mais admirar, se a manha da gente mascatal, se a cegueira da nobreza, e ganha foros de verossímil a história depois contada pelos mascates de que nada se previra, nada se preparara, tudo surgira de momento. Até hoje só têm triunfado no Brasil movimentos improvisados, que dispensam longas combinações e prodigalidades cerebrais.

Soldados do terço do Recife e os de Bernardo Vieira de Melo entraram em rusga por causa de mulheres à toa; o sargento-mor tomou o partido dos seus e exigiu o castigo dos outros; estes imploraram-lhe perdão, mas encontrando-o mal disposto e implacável, sairam para a rua disparando tiros, dando vivas ao rei e morras aos traidores, prenderam o cabo dos Palmares e levaram-no para a cadeia. O bispo e Valenzuela Ortiz, antigo 
juiz de fora que interinamente substituía a Arouche na ouvidoria, assistiram à prisão e aprovaram-na. Como por encanto ocupou as fortalezas a gente recifense; tudo isto a 18 de junho de 1711. No outro dia o bispo assinou comunicações às freguesias rurais aquietando-as. Se houvera de fato plano, a execução correu magistral: de um só golpe ficavam guarnecidas as fortalezas com pessoal amigo, imobilizado o mais resoluto cabecilha do grupo adverso e a legalidade de tudo atestada pela presença e aprovação explícita do chefe religioso e civil da capitania e de seu primeiro magistrado. Depois de três dias o bispo e o ouvidor sairam de Recife para Olinda, onde o inesperado dos sucessos provocara a maior agitação.

D. Manuel era varão virtuoso e letrado, mas facilmente sugestionável, timorato e violento a um tempo, impelido numa direção pelos ditames da consciência e logo atirado em sentido oposto pelas intrigas dos conselheiros. Sem grande custo convenceu-se na cidade de que os mascates quiseram prendê-lo, que a guarnição das fortalezas embuçava os mais negregados horrores e não podia, nem devia permitir desrespeito à majestade real depositada em suas mãos. Mandou diversas intimações aos do Recife para abandonarem as fortalezas, desvanecerem as fortificações feitas para terra, reconhecerem a fidelidade dos olindenses. Depois da quarta, tão inútil como as outras, a 27 de junho demitiu de si parte do poder temporal em favor de Valenzuela Ortiz, do mestre de campo Cristóvão de Mendonça Arrais, e oficiais do senado, "contanto que não haja efusão de sangue e assim o protesto uma e mil vezes, como já protestado tenho, e que para esta restauração e negócio e tudo o mais que dele se pode seguir, não concorro direta nem indiretamente, porque só quero a paz e sossego nos vassalos de Sua Majestade que Deus guarde".

Se quisesse tornar inevitável a efusão de sangue, o pobre prelado não teria achado melhor caminho. Escudada em sua cumplicidade, a nobreza cercou o Recife e as hostilidades abriram-se com violência de parte a parte. Bombardeios, sortidas, recriminações, folhas avulsas mostrando a semrazão dos adversários compõem este pouco interessante episódio. Comandava os mascates João da Mota, natural de Alagoas, elevado a capitão mandante por ser o oficial mais antigo. Era-lhe fácil manter a resistência, pois os sitiados sabiam que desta vez, se se rendessem, seria fatal o saque da vila. Dispunha a mais de sangue frio, bravura, entusiasmo, bom humor e presença de espírito. A exemplo do bispo, constituiu uma espécie de governo eclesiástico de frades, principalmente recoletos e carmelitas, letrados e canonistas, para contrabalançar as censuras e excomunhões episcopais. Nunca os mensageiros do prelado puderam fazer as intimações necessárias, e portanto ninguém se considerou nunca excomungado. A terrível arma mentiu fogo.

$\mathrm{Na}$ campanha houve dois combates: no primeiro venceram os mascates, no segundo os cidadãos. Apesar de seu furor partidário, o cronista olindense reconhece um quê de providencial no resultado dos dois encontros:

Mistérios foram ambas estas ocasiões da Divina Providência, que não permitiu o conseguir-se de outra sorte, livrando-nos sempre do maior mal, que por cegos o não víamos; pois é certo que se os nossos na primeira vez vencessem, como desejavam, escandalizados do seu atrevimento e sem o seu amparo os do Recife, entrariam de fora os moradores a abrasar quantos dentro nele achassem. E se nesta segunda batalha nos vencessem, vinham do mesmo modo sobre nós a acabar-nos.

A notícia dos primeiros sucessos chegou a Lisboa em fevereiro de 1711. Com eles ocupou-se o Conselho Ultramarino na consulta de 26. A impressão produzida foi veemente: "este caso não só é gravíssimo, mas o maior que até agora aconteceu na nação portuguesa", e a variedade nos alvitres, a virulência nas propostas, chegando um membro a fixar o mínimo dos que deveriam ser condenados à pena última, patentearam o soçobro dos conselheiros. Quase tanta indignação como o tiro e o levante suscitou a fuga de Sebastião de Castro, largando um governo de que prestara menagem nas mãos do soberano; o perigo da vida, mesmo se houvesse, não era o motivo para desculpá-lo.

Chegaram depois notícias mais tranquilizadoras: a posse do bispo, o perdão concedido aos revoltosos, a paz e a obediência sucedendo ao motim. A consulta de 8 de abril já revela mais calma. Só a 1 de junho, porém, o governo metropolitano resolveu confirmar o perdão, prender Sebastião de Castro por abandono do cargo, enviar novo governador, acompanhado de ouvidor, juiz de fora e alguma tropa.

Félix José Machado, nomeado governador, apareceu ao longe sobre Pau Amarelo em 6 de outubro, e logo os dois partidos mandaram a bordo expondo a seu modo o estado das cousas. Só então devia ter sabido do cerco do Recife e mais sucessos dele decorrentes. Exigiu que João da Mota 
entregasse as fortalezas, fez levantar o cerco e restituir toda a autoridade política a d. Manuel, de cujas mãos ùnicamente as receberia.

Estes atos revelaram espírito bem orientado, disposto a colocar-se sobranceiro às facções que se degladiavam. É bem possível mantivesse esta atitude até o fim se houvesse maneira de chegar a qualquer conciliação entre os combatentes, ou de arredar a questão fundamental: quem eram os verdadeiros criminosos? Os de Olinda que atentaram contra a vida de Sebastião de Castro, derribaram o pelourinho, queimaram as pautas eleitorais? Os do Recife que negaram obediência ao bispo-governador, guarneceram as fortalezas por autoridade própria, abocaram a artilharia contra a terra? Os cidadãos haviam sido anistiados pelo rei; o governador geral desde a Bahia anistiara os mascates, mas estes, desvanecidos e orgulhosos, diziam não precisar de perdão, antes reclamavam recompensas e agradecimentos.

A resposta seria fácil havendo terceiro levante, e logo um partido denunciou o outro de o estar tramando. A acusação era absurda, como o ato inexequível. Os de Olinda não tinham encontrado apoio ao Norte de Itamaracá ou ao Sul de Santo Agostinho; menos o encontrariam agora, com tropas vindas de Portugal e navios de guerra fundeados no porto. A gente mascatal obtivera a restauração da vila, o reerguimento do pelourinho, novas eleições: que mais poderia aspirar?

Entretanto, convenceu-se o governador de que os olindenses conspiravam, e logo começaram prisões, perseguições e processos. Ouvidores e desembargadores chamados a devassar o caso mostraram não só a parcialidade odienta a favor dos reinóis, como às vezes ordenaram prisões pelo simples desenfado de desfeitear o adversário e de se divertir com a gente de sua roda. O bispo teve ordem de sair de Olinda para o S. Francisco e como, por ser tempo das águas, viajasse devagar, intimou-lhe um desembargador que andasse mais depressa. Se a primeira dignidade eclesiástica não escapava destas afrontas, pode-se imaginar o que passariam pessoas sem imunidades. Foram anos bem calamitosos os de 1712 e 1713.

No fim deste, Antônio de Albuquerque, depois de ter governado Maranhão, Rio, S. Paulo e Minas, aportando a Pernambuco de passagem para a Europa, pode observar o estado de miséria e atribulação daquela pobre gente, e na corte expôs a verdadeira situação.
Os serviços prestados durante anos em cargos tão importante davam peso a suas palavras e a ele se atribuiu a disposição mais benévola desde logo mostrada. Cartas régias datadas de 7 de abril de 1714 lembraram que estavam perdoados tanto o levante de 1710 como o de 1711; não havia mais devassar e prender por causa deles; só constituía crime o de 1713.

Por implicados neste foram conservados presos Bernardo Vieira de Melo e um filho, Leonardo Bezerra e dois filhos, e Leão Falcão, o estouvado e leviano que, ainda depois da chegada de Félix José Machado, teve a veleidade de tentar resistir e insurgir-se, nos limites de Goiana, poderoso centro mascatal.

Leonardo Bezerra, depois de desterrado para a Índia, conseguiu fugir para a Bahia, onde terminou a vida. Segunda a tradição escrevia aos amigos: "não corteis um só quiri das matas; tratai de poupá-los para em tempo oportuno quebrarem-se nas costas dos marinheiros". Marinheiro era uma das designações dos portugueses na capitania de Pernambuco, quiri o nome de madeira tão rija como ferro. Se as palavras são autênticas, devia possuir otimismo incurável o velho insurgente que fiava a república ou a independência de sua pátria de costas e cacetes quebrados.

Entre estas agitações publicou-se na metrópole um livro intitulado Cultura e opulência do Brasil por suas drogas e minas, obra de André João Antonil, lê-se na primeira página da edição impressa com as licenças necessárias pela oficina real Deslanderina em 1711. Hoje sabemos que se tratava de anagrama e deve-se ler João Ant. Andreoni L. (luquense). Filho de Luca em Toscana, Andreoni veio ao Brasil em 1689 como visitador da Companhia de Jesus e terminada a comissão ficara na província. Ocupava o cargo de reitor da Bahia quando expirou Antônio Vieira, em 1697. Era provincial ao rebentar a guerra dos Mascates; há queixas, provàvelmente fideindignas, de haver manifestado simpatias a favor da nobreza de Olinda.

A obra de Andreoni, dividida em cinco partes, trata de engenhos e açúcar, de fumo, minas e gado. Sem amplificações, em forma tersa e severa, adunava algarismos e mostrava o Brasil tal qual se apresentava à visão de um espírito investigador e penetrante. Ficava-se agora sabendo da existência de cento e quarenta e seis engenhos, moentes e correntes na Bahia com a produção ânua de quatorze mil e quinhentas caixas de açúcar; de duzentos e quarenta e seis engenhos em Pernambuco;produzindo doze mil e trezentas caixas; de cento e trinta e seis engenhos no Rio, produzindo 
dez mil duzentas e vinte. Somava tudo trinta e sete mil e vinte caixas, de trinta e cinco arrobas cada uma, apurando 2.535:142\$800.

A Bahia produzia vinte e cinco mil rolos de fumo, Pernambuco e Alagoas dois mil e quinhentos, rendendo anualmente 334:650\$000.

No decênio anterior, a extração de ouro importaria mil arrobas; oficialmente andava agora por cem cada ano, mas a realidade importaria trezentas, uma por dia, descontados domingos e dias santos.

Para avaliar o gado bastava lembrar que os milhares de rolos de fumo iam encourados para bordo; além disso, Bahia exportava anualmente cinquenta mil meios de sola, Pernambuco quarenta mil e Rio, com os que iam da colônia do Sacramento, vinte mil, — ao todo cento e dez mil meios de sola, na importância de 201:800\$000.

E não são tudo estes 3.743:992\$800 da opulência do Brasil em favor de Portugal.

Cumpre acrescentar

o que rende o contrato das baleias que por seis anos se arrematou ultimamente na Bahia por 110 mil cruzados, o contrato anual dos dízimos reais, que na Bahia, nestes últimos anos, fora as propinas, chegou a perto de 200.00 cruzados; no Rio de Janeiro, por três anos, por 190.000 cruzados; em São Paulo por 60.000 cruzados, fora os das outras capitanias menores, que em todas notàvelmente cresceram; o contrato dos vinhos, que na Bahia se arrematou por seis anos 195.000 cruzados, em Pernambuco por três anos em 46.000 cruzados, e no Rio de Janeiro por quatro anos por mais de 50.000 cruzados; o contrato de sal na Bahia arrematado por doze anos a 28.000 cruzados cada ano; o contrato das águas ardentes da terra e de fora, avaliado por junto em trinta mil cruzados; o rendimento da Casa da Moeda do Rio de Janeiro, que, fazendo em dois anos três milhões de moeda de ouro, deu de lucro a el-rei, que o compra a doze tostões a oitava, mais de seiscentos mil cruzados; além das arrobas dos quinto que cada ano lhe vão; os direitos que se pagam nas alfândegas dos negros que vêm cada ano de Angola, S. Tomé e Mina em tão grande número aos portos da Bahia, Recife e Rio de Janeiro, a 3.500 réis por cabeça; e os dez por cento das fazendas no Rio de Janeiro, que importam um ano por outro oitenta mil cruzados.
A conclusão tirada destes algarismos escrupulosamente dispostos não podia ser mais modesta. Devem ser multiplicadas as igrejas, pois tanto cresce a população, amoestava o sagaz jesuíta; devem ser propostas pessoas idôneas nos concursos e provimentos das igrejas vacantes, pois tanto avultam os dízimos; deve-se pagar com pontualidade a soldadesca das praças e fortalezas marítimas e adiantá-la nos postos em igualdade de serviços; deve-se deferir as petições dos moradores, e aceitar os meios que para seu alívio e conveniência as câmaras tão humildemente propõem.

Se os senhores de engenhos e os lavradores do açúcar e do tabaco são os que mais promovem um lucro tão estimável, parece que merecem mais que os outros preferir no favor e achar em todos os tribunais aquela pronta expedição que atalha as dilações dos requerimentos, e o enfado e os gastos de prolongadas demandas.

O governo metropolitano deu ao livro uma resposta fulminante: confiscou-o, e com tamanho rigor que ainda hoje raríssimos exemplares se encontram da edição princeps. Pretextou para esta violência, estar divulgado nele o segredo do Brasil aos estrangeiros. Não se vê bem como podia fazê-lo: cultiva-se cana e fabricava-se açúcar em colônias de outras nações; plantava-se também fumo, criava-se gado, trafegavam-se minas. Que lhes poderia ensinar de novo a Cultura e opulência do Brasil por suas drogas e minas? A verdade é outra: o livro ensinava o segredo do Brasil aos brasileiros, mostrando toda a sua possança, justificando todas as suas pretensões, esclarecendo toda a sua grandeza.

Sob a arquitetônica severa dos algarismos colhidos pelo benemérito jesuíta conservou-se inviolado o segredo do Brasil aos brasileiros; transpirou, porém, sob outras formas, em adumbrações significativas.

Surdiu em ditirambos, exaltando a riqueza sem par do país. Apareceu em vastas compilações dedicadas à nobiliarquia, como a de Borges da Fonseca para Pernambuco, a de Jaboatão para a Bahia, e sobretudo a de Pedro Taques para S. Paulo, entroncando as famílias do Brasil na primeira nobreza de Espanha, Itália e Flandres. Como falecia-lhe senso histórico, Loreto Couto apanhou centenas de nomes para mostrar Pernambuco ilustrado com virtudes, com as letras, pelas armas, pelo sexo feminino.

No mesmo Loreto Couto, beneditino pernambucano que escrevia por 1757, encontramos manifestação ainda mais característica: o exalçamento, a 
glorificação do indígena, em confronto com a antiga gente de Portugal e até com povos mais adiantados do velho mundo.

Para provar suas virtudes morais, cita o nome de índios notáveis pelo valor e pela fidelidade, um Tabira, os Camarões e tanto outros auxiliares nas guerras flamengas e na conquista do país. Entre as manifestações de suas virtudes intelectuais aponta os conselhos em que os velhos da tribo discutiam as questões pendentes, o conhecimento das enfermidades e mezinhas, os ardis de caça e pesca.

Ignoravam a verdadeira religião? Não adoravam como os gentios antigos moradores da Beira e marinha de Setúbal uma baleia arrojada à praia, nem lhe ofereciam em sacrifício anualmente uma donzela e um moço.

Se os erros mui repugnantes aos princípios naturais provam barbaridade, é preciso declarar por bárbaros aos ingleses, dinamarqueses, suevos e muitos alemães, pois em todas estas nações está muito dominante o erro de que não pecamos por eleição, senão por necessidade, que Deus nos obriga a pecar e nos é impossível evitar o pecado.

Se tivessem cultura, desenvolveriam a inteligência.

No nosso reino de Portugal entre Celorico e Trancoso habitavam povos tão brutos e silvestres como animais indômitos, tão rudos que uma família não entendia a língua de outra com menos de duas léguas de distância, pelo que eram julgados pelos povos confinantes como bestas mais feras que as mesmas feras.

Entregavam-se à antropofagia?

Nem nos deve admirar a barbaridade destes povos, quando sabemos que dos descendentes de Tubal e de outras nações políticas com que se povoou Portugal se reduziram muitos dos seus descendentes a tanta brutalidade que matavam e comiam aos que dos povos vizinhos apanhavam ou em guerra ou em ciladas.

Servindo-se dos mesmos raciocínios, trata da língua geral cujas excelências celebra, da cor dos primitivos habitantes, etc. Suas ideias, discursivamente expostas e fundamentadas, aparecem sob forma sintética nos poetas contemporâneos; de modo ainda mais intuitivo revelam-nas os apelidos tomados na época da independência: Araripe, Braúna, Canguçu,
Guaicuru, Jucá, Montezuma, Mororó, Sucupira, Tupinambá e muitos outros. Por toda parte transparece o segredo do brasileiro: a diferenciação paulatina do reinol, inconsciente e tímida ao princípio, consciente, resoluta e irresistível mais tarde, pela integração com a natureza, com suas árvores, seus bichos e o próprio indígena.

Com ar triunfante, o escritor beneditino agita o decreto real de 4 de abril de 1755, declarando

que os meus vassalos deste reino e da América que casarem com as índias dela não ficam com infâmia alguma, antes se farão dignos de minha real atenção e que nas terras em que se estabelecerem serão preferidos para aqueles lugares e ocupações, que couberem na graduação de suas pessoas, e que seus filhos e descendentes serão hábeis e capazes de qualquer emprego, honra ou dignidade, sem que necessitem de dispensa alguma, etc.

Este decreto constitui episódio de longa história que se pode resumir em poucas palavras.

Apenas aportou à Bahia em 1549, Manuel da Nóbrega interessou-se pelos indígenas, por seu bem-estar físico, por sua formação espiritual e incorporação ao catolicismo. A experiência convenceu-o da necessidade, para colher resultado útil e duradouro, de isolar o indígena do colono, para afeiçoá-lo ao trabalho moderado, resguardar-lhe a segurança pessoal e garantir-lhe economia independente. Que fosse permitido escravizar índios, nunca contestou ele nem qualquer de seus sucessores: exigiram apenas o preenchimento de certas condições para a escravidão ser lícita. Cometeram um erro capital, mas inevitável: como poderiam negar o direito de cativar brasis, se os contemporâneos e as gerações seguintes durante mais de dois séculos reconheceram a escravatura africana?

Apesar de todos os embaraços criados pelas hesitações da metrópole e pelas paixões da colônia, a obra de Nóbrega prosseguiu e, na região amazônica sobretudo, prosperou. Aos missionários foi entregue a administração temporal das aldeias, cuja abastança e fartura excediam às das vilas dos brancos. Não se falava senão das riquezas dos jesuítas, e de fato sua parcimônia, gerência metódica e desapego pessoal figuravam uma magnificência de que levaram o segredo, como depois se verificou. 
Com o tempo as aldeias tornaram-se não só um estado no estado como uma igreja na igreja. O primeiro bispo do Pará quis chamar à sua jurisdição os missionários, mas estes, escudados em numerosos privilégios pontifícios e mercês régias, recusaram submeter-se. Suas razões deviam pesar alguma cousa, pois a decisão final exigiu largos anos.

Aos 24 de setembro de 1751 tomou posse do cargo em Belém Francisco Xavier de Mendonça Furtado, nomeado Governador Geral do Estado. Recomendavam-lhe suas instruções velasse pela liberdade dos índios e coibisse os excessos dos missionários. Uma excursão começada em Fevereiro do ano seguinte permitiu-lhe visitar as aldeias distribuídas entre a ilha de Marajó e o estreito de Pauxis. Em Caiá, ouvindo o discurso de um cacique, satisfeito com os melhores tempos que se anunciavam, exclamou: "E estes são os homens de quem se diz não têm juízo nem são capazes de nada! Deles se pode fazer uma nação como qualquer outra de que se pode tirar grande interesse".

Sua correspondência oficial neste e nos anos imediatos insiste na liberdade dos indígenas, nos abusos dos missionários, nos bens de raiz possuídos contra lei expressa, etc. Em fevereiro de 1754, escrevendo a Diogo de Mendonça Corte-Real, mostra-se convencido da impossibilidade de civilizar os índios com o auxílio dos regulares. Suas palavras eram genéricas, sem referência alguma especial à Companhia de Jesus. De suas reclamações resultaram duas leis, datadas de 6 e 7 de junho do ano seguinte, uma abolindo a administração temporal dos missionários nas aldeias, proclamando a outra mais uma vez a liberdade absoluta dos indígenas. Deixou-se ao arbítrio do governador geral o modo e a ocasião de publicálas.

Incumbido de dirigir a demarcação das fronteiras do Norte, Mendonça Furtado reclamou das aldeias as centenas de remeiros necessários ao progresso da comissão, os milhares de alqueires de farinha e outros gêneros necessários à manutenção de toda esta gente durante anos. $\mathrm{O}$ Pará moderno, servido por navios a vapor, comerciando com os dois mundos, estaria à altura de tamanhas exigências; não estava a Amazônia antiga, ocupada na extração do cravo, da salsa-parrilha, do cacau, sustentada quase exclusivamente pela pesca, muito feliz quando a pequena produção agrícola bastava para o consumo ordinário.
Mendonça parece não ter tido ideia clara desta situação, e todos os embaraços fatais, decorrentes da natureza das coisas, atribuiu às intrigas, à malevolência e perfídia dos jesuítas, criminosos obstinados e relapsos de uma monstruosidade sem nome: não terem domesticado as leis demográficas e econômicas às impaciências do irmão de Pombal. Para castigar tão nefando crime, reuniram-se as duas sociedades perfeitas; só uma expiação bastaria: extinguir a igreja na igreja, o estado no estado, que realmente era e não podia deixar de ser o regime dos aldeamentos.

Em 5 de fevereiro de 1757, Mendonça publicou a lei retirando aos missionários a administração temporal das aldeias, que deviam ter daí por diante uma organização puramente civil. Os missionários continuariam como párocos sujeitos à jurisdição do prelado. Todos sujeitaram-se a isto exceto os jesuítas por não lho permitirem suas constituições. Ofereceram-se para coadjutores, mas isto não aceitaram o governador nem o bispo.

Mendonça formulou um diretório em cerca de noventa e cinco artigos, datado de 3 de maio, para reger provisòriamente. Neste código da nova ordem de cousas, o missionário era substituído pelo diretor. A 14 do mesmo mês explicava esta criação do seguinte modo:

E não sendo possível que passassem [os índios] de um extremo a outro sem se buscar algum meio por que se pudesse chegar àquele importante fim, me não ocorreu outro mais proporcionado do que pôr em cada povoação um homem com o título de diretor, ao qual, sem ter jurisdição alguma coativa, lhe pertencesse só a diretiva para lhe ir ensinando não a forma de se governarem civilmente, mas a comerciarem de a cultivarem as suas terras, e tirarem destes frutuosos e interessantissímos trabalhos os lucros que eles sem dúvida alguma hão de dar de si e fazerem-se estes até agora desgraçados homens por esta forma cristãos, civis e ricos, que é o que sem dúvida alguma lhe há de suceder, se os diretores fizerem a sua obrigação.

Em seguida passou a elevar as aldeias maiores a vilas e as menores a lugares. Um contemporâneo, suspeito por ser jesuíta e não ter presenciado os sucessos, dá interessante descrição destas novidades; também sua cronologia não parece rigorosamente exata.

Veio-lhe pois ao pensamento dar o nome e os privilégios de vilas à semelhança das que há em Portugal a muitas aldeias que os índios habitavam, não obstante constarem todas de pobres, e rústicas 
choupanas, a exceção da igreja e casas dos párrocos. Para isto mandando levantar um grande pau no meio de um terreiro, dava a este sítio o nome de pelourinho; depois escolhendo entre todos aqueles selvagens alguns, que lhe pareceram ou pela fisionomia do rosto ou pela mole do corpo, mais hábeis para os empregos, a que os queria elevar, os constituiu como vereadores ou juízes dos mais, dizendo-lhes que eles eram tão bons, como os portugueses: que se governassem a si, sem dependência, ou sojeição alguma dos missionários. Além disto mandou vestir e calçar estas suas novas criaturas, assentá-las á sua mesa, fazendo-lhes nela muitos brindes, e ensinado-lhes inter pocula, por meio de um língua ou intérprete, o modo como se haviam de portar dali em diante, administrando a todos Justiça, etc. etc. Os Índios porém, acabada a comida, e companhia desfeita, esquecendo-se de quanto lhes tinha dito o senhor Mendonça, apenas sairam da sua presença tiraram os sapatos e vestidos e se emborracharam com os seus vinhos a que chamam mocòroròs, e em sinal de alegria e contentamento pelos cargos, a que tinham sido elevados, gritavam todos dizendo: Vinha del-rei, vinha del-rei, querendo dizer viva el-rei, viva el-rei. Mas passada a bebedice e tornando em si, se fizeram insolentes não só com os Missionários, perdendo-lhes o respeito e desobedecendo-lhes ainda nas cousas espirituais, senão também com os outros Indios; e isto com tal excesso, que saindo os Jesuítas e o mais Religiosos, que até ali foram párrocos nas Aldeias, além dos clérigos, que os substituíram, se viu o senhor Mendonça obrigado a mandar alguns portugueses com o título de diretores para os governar, e meter em sojeição: e ainda muitos destes portugueses repugnaram a ir para as novas vilas sem terem sempre consigo alguns soldados, que os defendessem dos insultos daqueles bárbaros.

Mendonça tratou em seguida da lei relativa à liberdade dos índios. Havia uma bula de Benedito XIV, passada em 20 de dezembro de 1741 a instâncias de d. João $\mathrm{V}$, cominando excomunhão latae sententiae a quem por qualquer motivo cativasse indígenas do Brasil. No panfleto pombalino intitulado Relação abreviada da república, etc., lê-se que o bispo do Pará d. Miguel de Bulhões ao tratar de executar a mesma bula se concitou contra ele uma sublevação que impediu por então aquela providência apostólica. A alegação é absolutamente caluniosa. Em data de 11 de junho de 1757 escrevia Mendonça Furtado: "cuja bula foi dada a este prelado por ordem de S. Majestade para publicar e fazer observar na sua diocese, o que pretendendo executar quando veio para esta cidade foi embaraçada pelos mesmos fundamentos com que eu suspendi a publicação da liberdade", etc. Os fundamentos para a suspensão da lei da liberdade foram meras considerações de oportunidade, como se verifica em toda a correspondência do governador geral; nunca houve sublevação. E tanta consciência tinha o escriba de estar caluniando, que acrescenta: "ao mesmo prelado não pareceu participar à corte uma tão estranha desordem, em tempo no qual a notícia de um tão escandaloso fato, temeu que alterasse a tranquilidade do ânimo do dito monarca, que já se achava com a grave enfermidade de que veio a falecer em 31 de julho de 1750". Assim se escreve a leitura.

A 25 de maio foi publicada a bula de Benedito XIV pelo bispo. A 28 Mendonça publicou a lei da liberdade dos índios. Não despertaram protestos, e diga-se a verdade, não foram respeitadas, apesar das aparências.

O diretório, aprovado pelo rei, vigorou de 1757 a 1798. As misérias provocadas por ele, direta ou indiretamente, são nefandas. Por fim d. Francisco de Sousa Coutinho teve compaixão dos índios e conseguiu a revogação. Chegava tarde a medida salvadora: o mal estava feito. Em 1850 o Pará e o Amazonas eram menos povoados e menos prósperos que um século antes; as devastações da cabanagem, os sofrimentos passados por aquelas comarcas remotas de 1820 a 1836 contam entre as raízes a malfadada criação de Francisco Xavier de Mendonça Furtado.

As leis retirando aos missionários a administração das aldeias e libertando os índios, ditadas só para o Estado do Maranhão, foram feitas extensivas ao resto do Brasil por alvará de 8 de maio de 1758. Também aqui miraculosamente pulularam as vilas, todas com legítimos nomes portugueses. Nestas partes a questão do indígena já perdera a importância, e as violências não foram tamanhas. Um escritor pernambucano das primeiras décadas do século passado mostra a situação antes ridícula que tétrica:

Os Índios têm vilas, e câmeras; e são nelas juízes, sem saberem nem ler, nem escrever, nem discorrer! tudo supre o escrivão; o qual, não passando muitas vezes de um mulato sapateiro, ou alfaiate, dirige a seu arbítrio aquelas câmeras de irracionais quase, pelo formulário seguinte:

$\mathrm{Na}$ véspera do dia, em que há de haver na aldeia vereação, parte o escrivão da sua moradia, se é longe; e neste caso sempre a cavalo; e vem dormir, nessa noite, em casa do senhor juiz, o qual 
imediatamente se encarrega do cavalo do senhor escrivão, leva-o a beber água; e por fim vai peá-lo aonde possa cômodamente pastar.

Fica entretanto o escrivão descansando, senhor aliás da casa, mulher, e filhas do oficioso juiz, que na volta lhe cede o melhor lugar da choupana, para dormir e passar a noite. Logo em amanhecendo começa o juiz a ornar-se com os velhos e emprestados arreios da sua dignidade, e a horas competentes marcha para um pardieiro, com alcunha de casa da câmera, aonde lidas as petições, que o escrivão fez na véspera, são despachadas pelo mesmo escrivão em nome do senhor juiz ordinário; e pouco depois se desfaz o venerando senado, e aparecem os senadores de camisa, e ceroulas, e de caminho para as suas tarefas.

A declaração da liberdade e o diretório dos índios foram seguidos de outras medidas em que igualmente colaboraram a igreja e o Estado. A Santa Sé nomeou visitador e reformador geral apostólico da Companhia de Jesus o cardeal F. de Saldanha, que contra os jesuítas vibrou um tremendo mandamento, subscrito a 15 de maio de 1758. A 7 de junho o patriarca de Lisboa suspendeu-os do exercício de confessarem e pregarem na sua diocese. Aproveitando uns tiros dados no rei, Pombal fez assinar pelo régio manequim uma lei declarando-os rebeldes, traidores, e havendo-os por desnaturalizados e proscritos.

No correr do ano seguinte foram embarcados para o Reino as centenas de sucessores de Nóbrega encontrados no Brasil. Durou duzentos e dez anos a sua atividade em nossa terra, e sua influência deve ter sido considerável. Deve ter sido, porque no atual estado de nossos conhecimentos é impossível determiná-la com precisão. No tempo de sua prosperidade publicaram apenas a redundante, deficiente e nem sempre fidedigna crônica de Simão de Vasconcelos, que vai só de 1549 a 1570. O que se encontra nas crônicas gerais, ânuas e outras publicações reduz-se às poucas páginas reunidas por A. H. Leal na Rev. Trim. do Inst. Hist. Biografias como as de Anchieta, Almeida, Vieira, Correia, pouco adiantam. Uma história dos jesuítas é obra urgente; enquanto não a possuirmos será presunçoso quem quiser escrever a do Brasil.

Nas suas diferentes casas devem ter ficado numerosos e importantes documentos, que o desleixo ou propósito aniquilou; salvaram-se apenas os títulos de suas propriedades. A julgar por algumas publicações e documentos fornecidos a Eduardo Prado e a Studart os arquivos europeus devem ser ricos.

Enquanto não se fizer a luz sobre tão obscuros assuntos, um juízo definitivo a respeito da famosa ordem pecará pela base. Em todo caso pouca, muito pouca inteligência revelam os ataques dirigidos contra ela. Instintivamente a simpatia volta-se para os discípulos e companheiros de Nóbrega, Anchieta, Cardim, Vieira, Andreoni, os educadores da mocidade, os fundadores da linguística americana. 